-Three Deposits of Strippable Lignite West of the

, Yellowstone River

\title{
Montana
}

GEOLOGICAL SURVEY BULLETIN 995-H

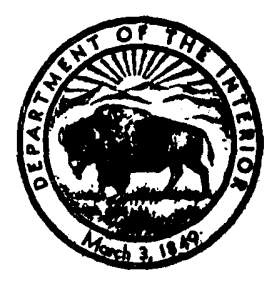





\title{
A CONTRIBUTION TO ECONOMIC GEOLOGY
}

\section{THREE DEPOSITS OF STRIPPABLE LIGNITE WEST OF THE YELLOWSTONE RIVER, MONTANA}

\author{
By Winliam C. Colbertson
}

ABSTRACT

An area of about 700 square miles west of the Yellowstone River, in southern Richland County and northern Dawson County, Mont., was investigated during 1951 for large deposits of lignite that could be recovered by strip-mining methods. Three such deposits are described in this report. For each deposit sufficient mapping was done to locate the line of outcrop of the lignite bed, and the three thickness-of-overburden contour lines that divide the deposit into areas in which the strippable coal is overlain by less than 60 feet, 60 to 90 feet, and 90 to 120 feet of overburden respectively.

Southern Richland County and northern Dawson County are part of the Great. Plains province. The topography consists predominantly of broad, flat uplandi surfaces, trenched by numerous wide, shallow valleys. About 90 percent of the area is underlain by the poorly indurated sandstones and shales of the Tongue River member of the Fort Union formation of Paleocene age, which, in about a third of the area, are covered with a veneer of terrace gravel. All the thick beds: of lignite, the thickest and most continuous of which is the Pust bed, are in the Tongue River member. The dips of the strata are low, about 10 to 50 feet per mile to the east and northeast in most of the area.

The Pust lignite is the strippable bed in the three deposits described in this report. On fresh exposure, the lignite is tough, black to brownish black and has a woody texture. The heating value on an as-received basis averages about 7,000 Btu, and the ash and sulfur contents are low. As the lignite slacks readily and tends to ignite spontaneously, special precautions must be used in storing or shipping. Overlying the lignite in all three deposits are soft shales and sandstones, which may be removed easily with the aid of light blasting.

The Fox Lake deposit is about 2 miles southwest of Lambert. In this area the Pust bed ranges in thickness from 7 to 17 feet, averages 11 feet thick, and at most places contains one parting. The deposit contains 46 million tons of lignite under less than 120 feet of overburden in an area of 2,400 acres. The Breezy Flat deposit is 4 miles west of Savage and the same distance west of the Yellowstone River. Here, the Pust bed ranges in thickness from 9 feet to more than 25 feet and averages 14 feet thick. The reserves total 220 million tons in an area of 8,900 acres. The North Fork Thirteenmile Creek deposit is the largest of the three deposits. It is about 6 miles north of Bloomfield and 12 miles southeast of Richey. The lignite is from 10 to 43 feet thick and averages about 25 feet. The 
deposit contains 225 million tons under less than 120 feet of overburden in an area of 5,200 acres. The reserves of strippable lignite in the three deposits total 491 million tons.

\section{INTRODUCTION}

The tremendous reserves of lignite in the Powder River-Fort Union coal region (fig. 38) constitute one of the largest sources of potential fuel and power in the Nation. As the coal is of low rank and consequently sells at low prices, utilization of these reserves is to a considerable degree contingent upon low-cost recovery. The region is particularly well suited to large-scale stripping, the lignite beds being thick, extensive, and nearly flat and in large areas lying at shallow depths. Further, the overlying rocks are relatively soft and easily removed. The efficiency of strip mining in this region is shown by the record of one large strip mine at Colstrip, Mont., which produced $1,708,149$ tons of subbituminous coal in 1950 at the rate of 92.78 tons per man-day (U. S. Bureau of Mines, 1951, p. 20).

In view of such a record the trend toward strip mining in the region may be expected to continue and to accelerate in the foreseeable future, thus pointing to the necessity for information about areas adapted to strip mining. This report describes three deposits in northern Dawson County and southern Richland County, Mont., which contain 491 million tons of lignite under less than 120 feet of overburden. (See table 1.) This general area was selected for study because previous investigations by the U. S. Geological Survey indicate the presence of thick coal beds under the thin cover; it is reasonably close to the Yellowstone River; and it is well served by railroads. (See fig. 39.)

TaBLe 1.-Original reserves of strippable lignite in three selected deposits west of the Yellowstone River in northern Dawson County and southern Richland

[In millions of short tons]

\begin{tabular}{|c|c|c|c|c|c|c|c|c|c|}
\hline \multirow{2}{*}{ Deposit } & \multirow{2}{*}{$\begin{array}{l}\text { Avei- } \\
\text { age } \\
\text { thick- } \\
\text { ness } \\
\text { (in feet) }\end{array}$} & \multicolumn{2}{|c|}{$\begin{array}{l}\text { Less than } 60 \text { feet } \\
\text { overburden }\end{array}$} & \multicolumn{2}{|c|}{$\begin{array}{c}60-90 \text { feet } \\
\text { overburden }\end{array}$} & \multicolumn{2}{|c|}{$\begin{array}{l}90-120 \text { feet } \\
\text { overburden }\end{array}$} & \multicolumn{2}{|c|}{ Total } \\
\hline & & Acres & Reserves & Acres & Reserves & Acres & Reserves & Acres & Reserves \\
\hline Fox Lake & 11 & 1,878 & 36.2 & 294 & 5.7 & 228 & 4.4 & 2,400 & 46.3 \\
\hline $\begin{array}{l}\text { North Fork Thirteenmile } \\
\text { Creek: } \\
\text { T. } 21 \text { N., R. } 53 \mathrm{E} \\
\text { T. } 20 \text { N., R. } 53 \mathrm{E} \\
\text {. T. } 20 \text { N., R. } 54 \mathrm{E} \\
\end{array}$ & $\begin{array}{l}19 \\
21 \\
35\end{array}$ & $\begin{array}{l}763 \\
710 \\
851\end{array}$ & $\begin{array}{l}25.4 \\
26.0 \\
52.1\end{array}$ & $\begin{array}{l}824 \\
238 \\
514\end{array}$ & $\begin{array}{r}27.4 \\
8.8 \\
31.5\end{array}$ & $\begin{array}{l}695 \\
238 \\
359\end{array}$ & $\begin{array}{r}23.2 \\
8.7 \\
22.0\end{array}$ & $\begin{array}{l}2,282 \\
1,186 \\
1,724\end{array}$ & $\begin{array}{r}76.0 \\
43.5 \\
105.6\end{array}$ \\
\hline $\begin{array}{l}\text { Total-North Fork } \\
\text { Thirteen mile } \\
\text { Crcek }\end{array}$ & $\begin{array}{l}25 \\
14\end{array}$ & $\begin{array}{l}2,324 \\
2,839\end{array}$ & $\begin{array}{r}103.5 \\
69.6\end{array}$ & $\begin{array}{l}1,576 \\
4,847\end{array}$ & $\begin{array}{r}67.7 \\
118.7\end{array}$ & $\begin{array}{l}1,292 \\
1,277\end{array}$ & $\begin{array}{l}53.9 \\
31.3\end{array}$ & $\begin{array}{l}5,192 \\
8,963\end{array}$ & $\begin{array}{l}225.1 \\
219.6\end{array}$ \\
\hline Total. & $\ldots$ & 7,041 & 209.3 & 6,717 & 192.1 & 2,797 & 89.6 & 16,555 & 491.0 \\
\hline
\end{tabular}




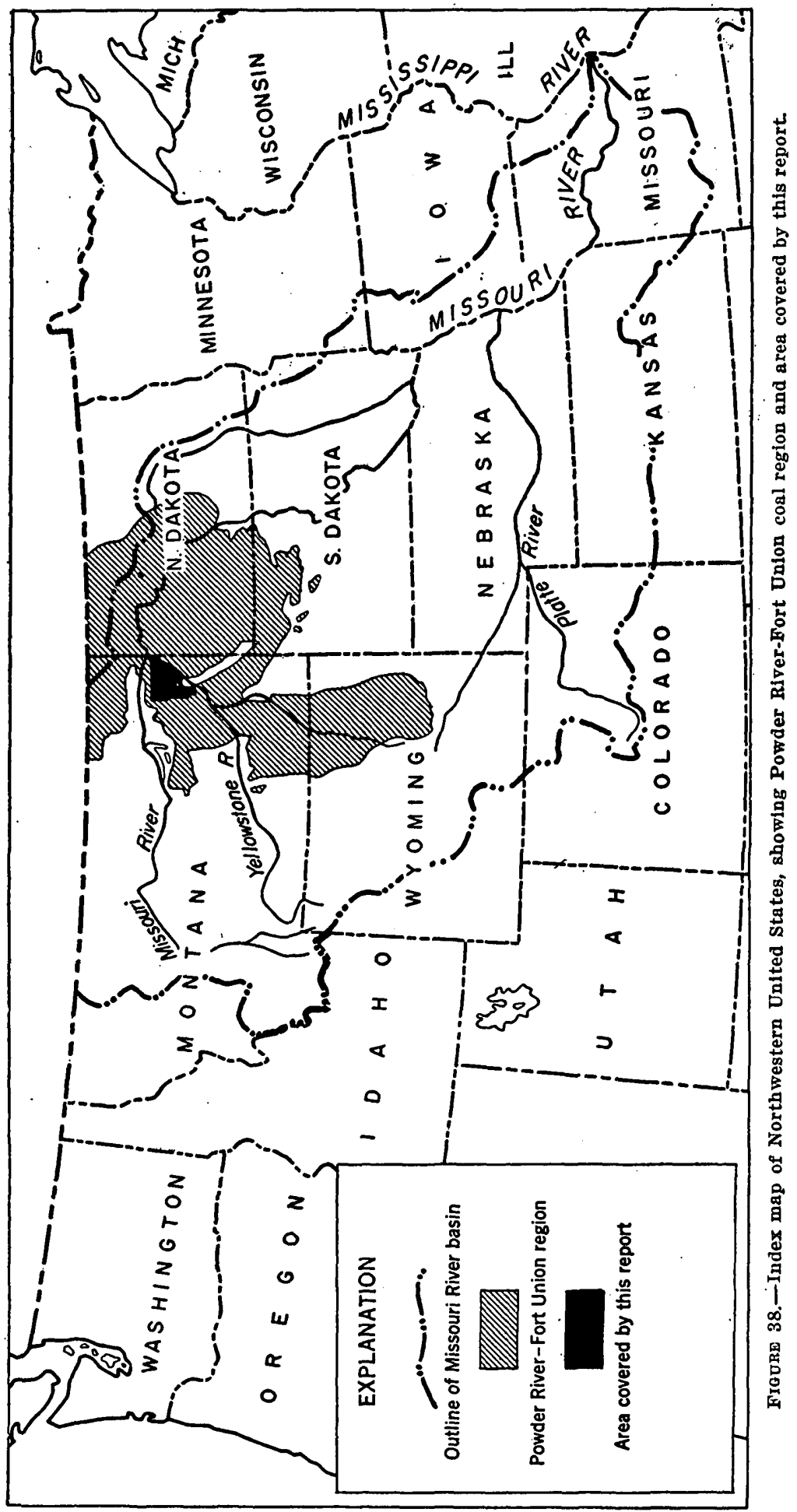




\section{LOCATION OF THE AREA}

The area covered by this report is divided into two parts and comprises about 700 square miles west of the Yellowstone River in southern Richland County and northern Dawson County, Mont. (See fig. 39.) The southeastern part includes those townships in the Sidney and Glendive lignite fields (see fig. 40) that lie west of the Yellowstone River, south of the south line of township 21 north, and north of the north line of township 15 north, except for T. 16 N., R. 53 E. The

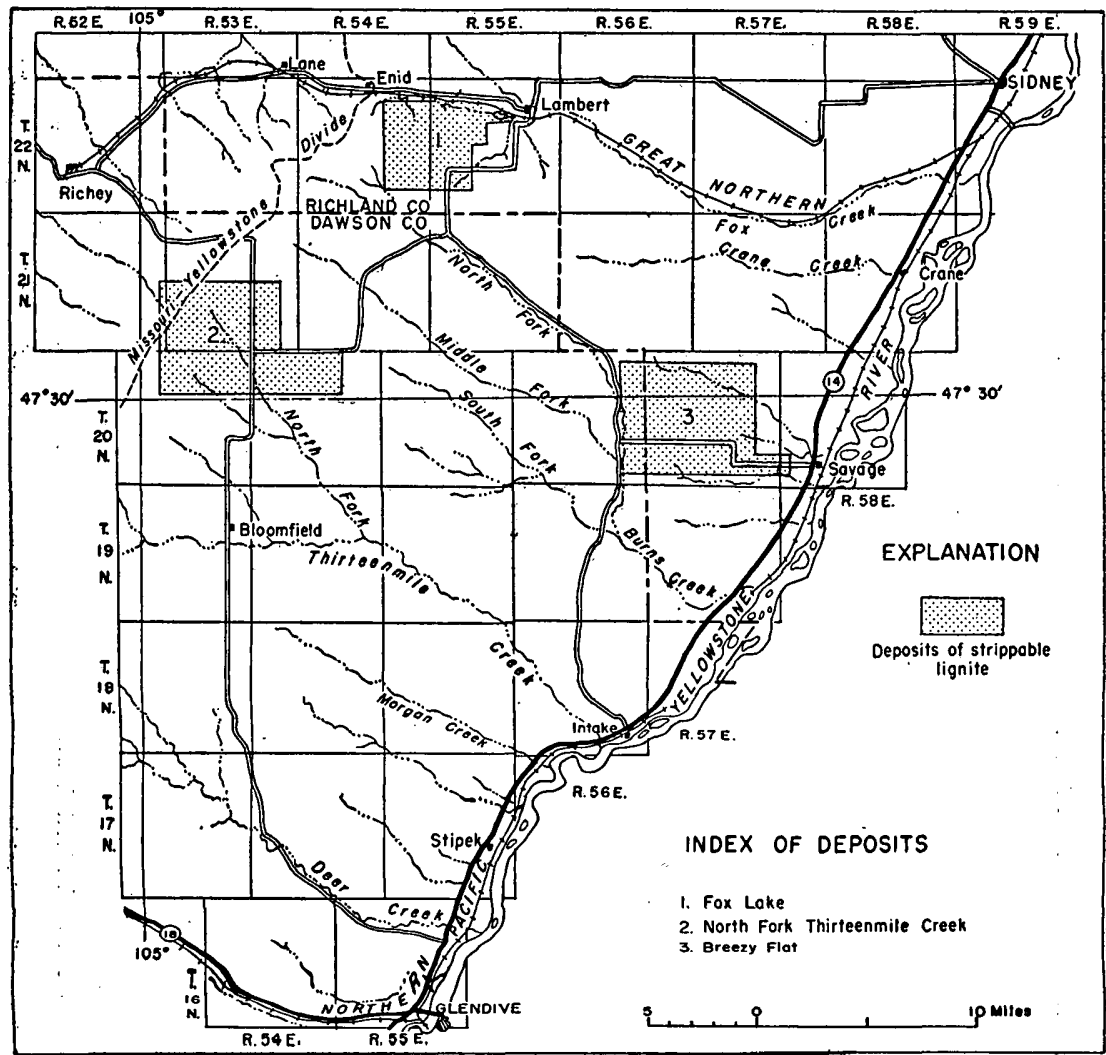

Frg drw 39.-Index map of southern Richland County and northern Dawson County, Mont., west of the Yellowstone River, showing deposits of strippable lignite described in this report.

northern part consists of the southern $2 \frac{1}{3}$ tiers of townships of the Richey-Lambert coal field (fig. 40) that lie east of the east line of R. $51 \mathrm{E}$.

Adjoining the two parts of the investigated area on the north and east is the Girard Coal field (Prichard, in files of U. S. Geol. Survey, Washington 25, D. C.). As the coal beds to the south and west have not been mapped, that area was investigated, for the purposes of the present report, only where a strippable deposit extended into it. 


\section{PREVIOUS GEOLOGIC WORK}

The southern part of the area covered by this report was mapped in 1910 by Stebinger and Hance as part of a program to classify the land as coal or noncoal land for the purposes of the Homestead Act. Their work, which was of a reconnaissance nature, was published in 1912 as the Sidney lignite field (Stebinger, 1912, p. 284-318). and the Glendive lignite field (Hance, 1912). In 1930 Parker mapped in detail the geology and coal resources of the northern part of the

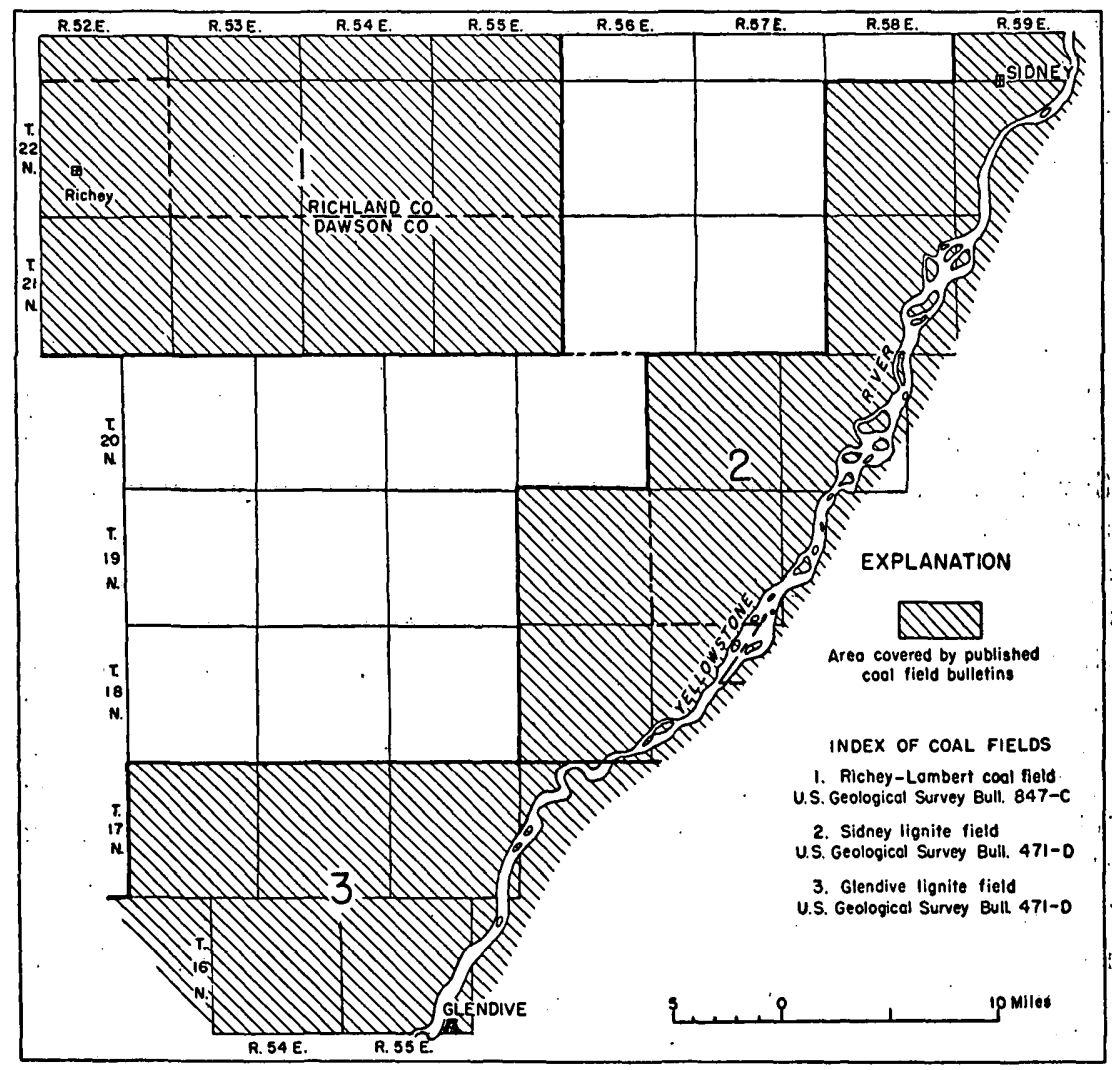

Figure 40.--Index map of southern Richland County and northern Dawson County, Mont.; west of the Yellowstone River, showing coal flelds described in U. S. Geological Survey. Bulletins.

investigated area (Parker, 1936, p. 121-148). Figure 40 shows the location of these fields insofar as they lie within the area covered by this report. W. C. Alden visited this region to study the glacial and physiographic features (Alden, 1932). The writer has drawn freely from each of these publications in preparing the present report.

Three other areas in eastern Montana are currently being investigated for deposits of strippable coal by the U. S. Geological Survey: Southern Custer County and northern Powder River County, Mont. 
(Brown and others, 1954), central Rosebud County, Mont. (Kepferle, 1954), and the Wibaux area, Mont. (May, 1954).

\section{ACKNOWLEDGMENTS}

The writer wishes to express his appreciation for the aid and cooperation given to him by the farmers, ranchers, and mine owners of the region. Mr. Burt Fuller of Epworth, Mont.; Mr. Whitmer of Circle, and Mr. J. B. Leas of Glendive, Mont., generously provided logs of water wells they had drilled. Mr. Jacob Albrecht assisted in the collection of a sample of lignite from his mine.

The field work forming the basis for this report was done during the latter half of 1951. Mr. Paul May assisted the writer for a short time at the beginning of the summer.

\section{GEOGRAPHY}

\section{TOPOGRAPHY}

The area covered by this report is part of the Northern Great Plains Province and consists of broad, rolling upland surfaces trenched by tributaries of the Yellowstone and Missouri Rivers. These streams flow in shallow, troughlike valleys, which have nearly level floors a quarter of a mile to two miles wide. The area between the upland surfaces and the valley floors is usually a zone of steep, irregular slopes that locally have the character of badlands. In some places the differential erosion of hard and soft sediments has produced flattopped ridges and buttes. On the west side of the Yellowstone River, the uplands consist of a series of as many as four terraces, half a mile to three miles wide, which extend for many miles along the river. The terraces give a steplike appearance which is in sharp contrast to the generally rugged topography on the east side of the Yellowstone. The presence of terraces on only the west side of the river is attributed to regional tilting which caused the Yellowstone River to migrate eastward as it was cutting its valley.

The Missouri River-Yellowstone River divide, which trends northeastward across the northern part of the area, is the highest part of the area, reaching 3,117 feet above sea level at Clay Butte in sec. 17, T. 21 N., R. 53 E. . The northwest side of this divide is a rough escarpment; on the southeast side the land slopes away gently to form the upland surface called the Retah Table. The total relief of the area is about 1,000 feet, but rarely exceeds 300 feet locally.

\section{DRAINAGE AND WATER SUPPLY}

All of the investigated area drains into the Yellowstone River except the northwestern corner, which drains into the Missouri River through 
Redwater Creek and its tributaries. The Yellowstone tributaries are predominantly parallel and flow in a southeasterly direction; those of Redwater Creek flow northwestward.

The tributary streams of the Yellowstone and Missouri Rivers have a good flow of water during heavy rainstorms and after the spring thaw. During the remainder of the year, the smaller streams are are dry and the larger ones, such as Redwater, Burns, Thirteenmile, and Deer Creeks, either are reduced to a trickle or merely have pools of water standing in the channel. Although the flow of these streams appears small, it is probable that a considerable amount of water migrates downstream in the alluvial sand beneath the surface.

The Yellowstone River contains the only large supply of water within the investigated area. At Sidney the discharge of the river (see table 2) averaged 8,397,200 acre-feet per year from 1935-50. The actual flow, however, varies seasonally, reaching its maximum during the late spring and early summer and its minimum in the winter when the river is frozen over. During the summer a large amount of the water from the Yellowstone is used for irrigation purposes. Most of this water is drawn off at Intake, about 30 miles upstream from the gaging station at Sidney.

The only permanent lake is Fox Lake, a small body of water in a marshy area west of Lambert. Although the lake is persistent throughout the year, the size varies considerably. During periods of heavy rain it occupies the entire swamp area, but during dry periods the water surface is hidden by marsh plants, and an alkali flat surrounds the marsh.

Groundwater is obtained in amounts sufficient for domestic use from shallow wells in the alluvium of the stream valleys or in the terraces adjoining them. This water is hard and contains so much dissolved mineral matter that much of it is distasteful to drink. Some water is obtained from lignite beds, and this is commonly brownish and has a sulfurous odor and taste. Wells penetrating about 200 feet into Fort Union rocks usually obtain a fairly good supply of soft water, though it too has a high mineral content. The amount of available groundwater is inadequate for large industrial uses.

\section{CLIMATE}

The climate in southern Richland County and northern Dawson County is semiarid. The average annual precipitation is about 15 inches, of which 10 inches falls as rain from April to September, the remainder falling as snow during the other six months. The winter temperatures average about $20 \mathrm{~F}$ but may drop to as low as $-40 \mathrm{~F}$. Windstorms occur occasionally and, when combined with snow and low temperatures, result in blizzards that paralyze transportation. 


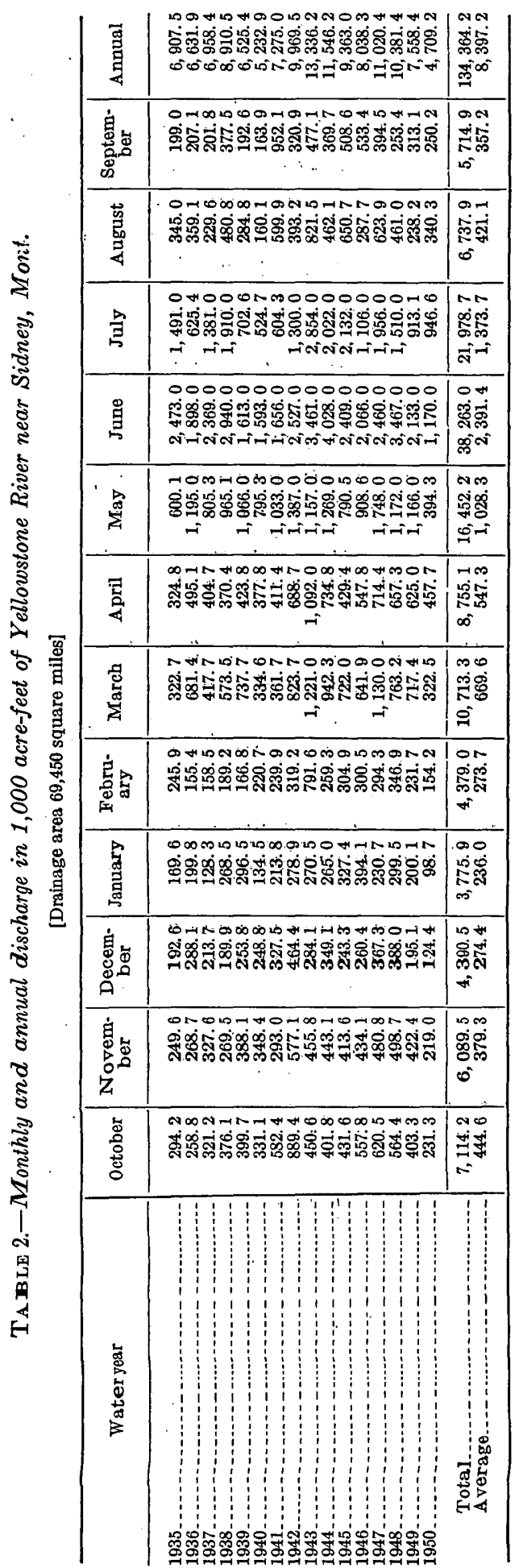

$x$ 
The summer temperatures average about 70 $\mathrm{F}$ but for short periods may reach $100 \mathrm{~F}$. The summer season is short, and below-freezing temperatures may be expected as early as the middle of September and as late as the middle of May.

\section{SETTLEMENT}

According to the 1950 census of towns in Dawson and Richland Counties, Glendive (pop. 5,254), the county seat of Dawson County, is the largest; the next largest is Sidney (pop. 3,987), the county seat of Richland County, and the third largest is Richey (pop. 595). All of the other towns are small farming communities, the largest of which are Savage and Lambert whose populations are estimated at 300 and 250 respectively. The remainder of the population, totaling nearly 9,000 , lives on farms and ranches. The population density of the rural area is about one person per square mile. The greatest concentration of farms is along the Yellowstone River where a large supply of irrigation water is available.

Although the population of this area has shown little increase in the past 10 years, the discovery of oil near Richey and Glendive in 1951 caused a large influx of people to these towns.

\section{TRANSPORTATION}

Southern Richland County and northern Dawson County are served by two branch lines of the Northern Pacific Railway and one branch line of the Great Northern Railway. The two Northern Pacitic branch lines leave the main line at Glendive; one follows the Yellowstone River northeastward to Sidney, and the other goes northwestward to Circle. The branch line of the Great Northern leaves the main line at Snowden, Mont., and extends westward through Sidney and Lambert to Richey, Mont.

The two major highways crossing the area are the well-drained gravel-surfaced highway from Sidney to Richey and the highway from Glendive to Richey by way of Bloomfield. Both of these roads are passable the year around. The other county roads are gravel- or clinker-surfaced, but generally are not well drained and are often impassable after heavy snows or rainstorms.

Two asphalt-paved highways adjoin the area. One of these, State Highway 14, parallels the Yellowstone River and the Northern Pacific Railway from Glendive to Sidney; and the other, State Highway 18, follows the other North Pacific line from Glendive to Circle.

\section{ELECTRIC POWER}

The main source of electric power in eastern Montana is the power plant at the Fort Peck Dam on the Missouri River. From the dam, a 
115-kilovolt transmission line extends through Wolf Point, Circle, and Lindsay to Glendive. In 1952 the Bureau of Reclamation constructed an extension of this line which follows the Yellowstone River down to Sidney. This extension parallels the 57-kilovolt transmission line owned by the Montana-Dakota Utilities Company.

Just north of Lindsay the McCone County Electric Co-Operative Inc. operates a substation, with a capacity of $1,000 \mathrm{kva}$ from which a 3 -phase transmission line extends to a point 11/2 miles north of Bloomfield. This organization also owns a $600 \mathrm{kva}$ substation, located 20 miles north of Circle, which has a 3-phase line extending to Richey.

\section{LAND USE}

Most of the land in southern Richland County and northern Dawson County is used for the raising of livestock. The valley of the Yellowstone River is devoted principally to irrigation farming, for which there is an abundant supply of water from an irrigation canal constructed by the U. S. Bureau of Reclamation. The principal crops are corn, sugar beets, hay, and small grains. Dryland farming is practiced on much of the flat upland surfaces where wheat is the principal crop.

\section{LAND OWNERSHIP}

Most of this area lies within the Northern Pacific Railway land grants under which the railroad was given title to all odd-numbered sections, except those that had already been homesteaded, in every township for 60 miles on each side of the right-of-way. The State of Montana was given sections 16 and 36 from each township for use as school lands. The remainder of the land was retained as property of the Federal Government until homesteaded or sold. The railroad has since sold or traded much of its land, but it has kept the mineral rights to most of the property. The Government has disposed of its botter tracts of lands, although the mineral rights on some have been retained. As a rule, the State of Montana has retained the surface and mineral rights to its school lands.

\section{STRATIGRAPHY}

The rocks exposed in southern Richland County and northern Dawson County are all of sedimentary, nonmarine origin and range in age from Late Cretaceous to Recent. They are represented by an undivided section of rocks of Late Cretaceous and early Paleocene age, the Tongue River member of the Fort Union formation of Paleocene age, terrace gravel deposits of middle Tertiary to Quaternary age, and Recent alluvium. Of these rock units, the Tongue River member of the Fort Union formation is of primary importance in this report, because it contains all of the thick beds of lignite in the region. 


\section{UNDIVIDED SECTION}

Cropping out at the southernmost tip of the investigated area is an undivided section of about 500 feet of dark shales, local beds of calcareous sandstone, and in the upper part a few thin lenticular beds of lignite. (See pl. 44.) Calvert (1912, p. 195) called this section the upper or undivided part of the Lance formation. Later work in areas to the north has indicated that it probably represents the Hell Creek formation of Late Cretaceous age, the Tullock member of the Fort Union formation of Paleocene age, and possibly the. Lebo shale member of the Fort Union formation. These rocks are relatively soft and erode easily to form badlands.

\section{FORT UNION FORMATION}

The Fort Union formation is the most widespread surface rock in eastern Montana. It normally contains three members; the Tullock, Lebo shale, and Tongue River. In this area only the Tongue River member is definitely identified. A fourth member, the Sentinel Butte shale, overlies the Tongue River member in the areas to the north and east, but erosion has removed all trace of it in the area being discussed.

Tongue River member.-Except for a thin cover of terrace gravels, the Tongue River member is the surface rock over about 90 percent of the area covered by this report. In the northern part of the area where the upper part of the member is exposed, it is composed predominantly of thick, cross-bedded or massive beds of yellow, lightbuff, or white, fine-grained, friable sandstone interbedded with lightgray, poorly indurated shale and, locally, a few thin beds of fresh water limestone. (See pl. 45-A) In the southern part of the area, where the lower part of the member is exposed, the yellow color is less noticeable and darker shades of gray predominate. The Tongue River member contains many beds of lignite; several of which, in the lower half of the section, are thick and continuous. At many places, however, the thicker beds are burned at the outcrop and for some distance underground. The resultant heat has baked and fused the overlying sandstones and shales into clinker, which is usually red or brownish red, highly resistant to erosion, and one of the most distinctive rocks of the member.

The thick lignite beds and the accompanying masses of clinker are the only continuous units within the member; the sandstone and shale beds generally show abrupt lateral alternations. A sandstone, for example, will grade into a shale within a very short distance so that a section measured at one place cannot be matched in detail with one a few hundred feet away.

The contact of the Tongue River member with the underlying rocks is marked by an upward transition in color from the several shades 
of dark gray and brown of the undivided section to the lighter shades of gray and yellow of the Tongue River member. This transition is difficult to distinguish in the southern part of the area, but bed A of the Sidney lignite field (Stebinger, 1912) and its correlative, the "lowest minable bed" of the Glendive lignite field (Hance, 1912), mark its approximate location.

The land surface formed on the rocks of the Tongue River member is generally a rolling, grass-covered slope, cut in a few places by gullies. Locally, however, it is a highly dissected escarpment, as on the northwest side of the Missouri River-Yellowstone River divide. Here a typical badland topography, featured by long, narrow spurs, sharp peaks, and small buttes, has been formed.

The full thickness of the Tongue River member is not present in this area, the upper part having been removed by erosion. The maximum thickness of the remaining section is about 950 feet (Parker, 1936, p. 130).

\section{TERRACE GRAVEL DEPOSITS AND ALLUVIUM}

Overlying the Tongue River member in many parts of the area is a series of at least five terrace gravel deposits, the highest of which is a maximum of 1,200 feet above the Yellowstone River. The terraces cover nearly one-third of the surface of the area investigated, principally the flat to rolling uplands.

The highest terrace gravel probably represents a once extensive deposit, but it now caps only a few high hills and ridges near the crest of the Missouri-Yellowstone River divide in T. 21 N., R. 53 E. According to Parker (1936, p. 132) this gravel is probably of Oligocene or Miocene age. It is composed of well-rounded pebbles, oneeighth to three inches in diameter, of various igneous and metamorphic rocks, including quartzite, granite, and volcanic rocks, in a matrix of fine gravel, sand, and silt. The gravel is generally unconsolidated and, àt the best exposures, is as much as 15 feet thick.

The second highest terrace gravel deposit is the most widespread. It is tentatively correlated with the Flaxville gravel of Miocene or Pliocene age and covers more than a hundred square miles of upland surfaces, principally in the northern part of the area on the southeast flank of the Missouri-Yellowstone River divide. It generally lies at an altitude of 2,700 to 2,900 feet above sea level. The deposit is commonly as much as 30 feet thick and is of much the same composition as the gravel above it.

Below the widespread Flaxville (?) surface are local stream terraces. Some of them cover only a small area, as, for example, the deposit of terrace gravel on the west side of the valley of the North Fork of Thirteenmile Creek in T. 20 N., Rs. 53 and 54 E. On the west side 
of the Yellowstone River, however, there are two lower terraces, called bench 2 and bench 3 by Alden (1932), which extend for many miles and are a maximum of 2 miles wide. The higher of these two terraces is about 400 feet above the Yellowstone River at Savage. It covers the surface of Breezy Flat and is 5 to 30 feet thick. This deposit is presumably a reworking of the higher gravel deposits, for it is similar to them in composition. The second terrace, bench 3 , is a cut terrace and is covered with only a thin veneer of gravel. Still lower is a wide flood plain deposit of the Yellowstone River upon which stands the town of Savage. The river has resumed its downcutting action since the formation of this flood plain and now flows in a channel 50 to 100 feet below.

The age of these stream terraces is not known, but the presence of glacial rocks on the surface of the highest of these, bench 2 , indicates that it was formed before the Pleistocene glaciation.

Alluvial fill covers the bed rock in the bottom of all the larger streams to a depth of 30 feet or more. The alluvium, probably Recent in age, is generally composed of sand, silt, clay, and some lenses of gravel.

\section{GLACIAL ROCKS}

The surface of the high stream terrace is Tps. 19 and 20 N., R. 57 E., is dotted with boulders that were carried there during either the Illinoian or early Wisconsin stage of glaciation by a large ice sheet that extended southward down the valley of the Yellowstone River as far as Intake (Alden, 1932, p. 82). These boulders, 1 to 5 feet in diameter, are principally granite or limestone.

\section{STRUCTURE}

Southern Richland County and northern Dawson County west of the Yellowstone River are on the west side of a broad synclinal depression, the Williston Basin, whose center is near Williston, N. Dak. The southern part of the area is on the gently dipping, northeastern limb of the Cedar Creek anticline, a long linear uplift whose axis trends northwest and passes about 8 miles southwest of Glendive, Mont. The dip of the beds is slight, generally ranging from 10 to 50 feet per mile but increasing to as much as 250 feet per mile near the anticline. The direction of the dip is toward the center of the Williston Basin and thus is predominantly northeastward in the southern part of the area and eastward in the northern part. In addition to this regional dip, the coal beds show minor undulations, the local structural relief usually being about 10 to 20 feet. The presence of major undulations, having widths of several miles and heights of 50 feet or more, are also indicated by observations on the coal beds; 
but the nature of the present investigation precluded any detailed structural mapping to confirm these indications., No faulting was observed in the area.

\section{LIGNITE}

The coal in the Fort Union region increases in rank from east to west across North Dakota and Montana, and the boundary between lignite and subbituminous coal lies west of the area covered by this report. As might be expected from this geographic location, the lignite is somewhat higher in heat value on a moist, mineral-matter-free basis than North Dakota lignite and is somewhat lower in heat value than the subbituminous coal that lies farther west.

TABLE 3.-Analyses of coal from Dawson and Richland Counties, Mont.

[Analyses by U. S. Bureau of Mines]

\begin{tabular}{|c|c|c|c|c|c|c|c|c|c|}
\hline $\begin{array}{l}\text { Labora- } \\
\text { tory } \\
\text { number }\end{array}$ & Source & $\begin{array}{c}\text { Form of } \\
\text { Analy }- \\
\text { sis } 1\end{array}$ & $\begin{array}{l}\text { Mois- } \\
\text { ture }\end{array}$ & $\begin{array}{c}\text { Vola- } \\
\text { tile } \\
\text { matter }\end{array}$ & $\begin{array}{c}\text { Fixed } \\
\text { carbon }\end{array}$ & Ash & Sulfur & $\begin{array}{l}\text { Air- } \\
\text { diry } \\
\text { loss }\end{array}$ & $\begin{array}{l}\text { Heating } \\
\text { valine } \\
(\mathrm{B}: \mathrm{u})\end{array}$ \\
\hline A-65451 & $\begin{array}{l}\text { Jower Elviro bed, EIviro mine, } \\
\text { sec. 12, T. } 24 \text { N., lR. } 54 \text { E., } \\
\text { Richland Co. }\end{array}$ & $\begin{array}{l}\mathbf{A} \\
\mathbf{B} \\
\mathbf{C}\end{array}$ & $\begin{array}{r}38.3 \\
\hdashline-2 . \\
\hdashline-2 .\end{array}$ & $\begin{array}{l}25.7 \\
41.6 \\
46.1\end{array}$ & $\begin{array}{l}30.0 \\
48.6 \\
53.9\end{array}$ & $\begin{array}{l}6.0 \\
9.8\end{array}$ & $\begin{array}{l}0.5 \\
0.8 \\
0.9\end{array}$ & 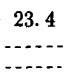 & $\begin{array}{r}6,710 \\
10.880 \\
12,060\end{array}$ \\
\hline$A-65454$ & $\begin{array}{l}\text { Lane bed, Lane mine, sec. } 26, T \text {. } \\
23 \text { N., R. } 53 \text { E., Richland Co. }\end{array}$ & $\begin{array}{l}\text { A } \\
\text { B } \\
\mathbf{C}\end{array}$ & $\begin{array}{r}36.5 \\
-2 . . \\
\hdashline-2 .\end{array}$ & $\begin{array}{l}26.9 \\
42.4 \\
47.4\end{array}$ & $\begin{array}{l}30.0 \\
47.2 \\
52.6^{3}\end{array}$ & $\begin{array}{r}6.6 \\
10.4\end{array}$ & $\begin{array}{l}0.9 \\
1.4 \\
1.5\end{array}$ & \begin{tabular}{ll}
21.5 \\
\hdashline..-
\end{tabular} & $\begin{array}{r}7,150 \\
11,250 \\
12,560\end{array}$ \\
\hline A- 65452 & $\begin{array}{l}\text { Carroll bed, Carroll mine, sec. 8, } \\
\text { T. } 22 \text { N., R. } 51 \text { E., Dawson Co. }\end{array}$ & $\begin{array}{l}\mathrm{A} \\
\mathrm{B} \\
\mathrm{C}\end{array}$ & $\begin{array}{r}33.0 \\
\hdashline-2 .\end{array}$ & $\begin{array}{l}25.5 \\
38.1 \\
41.5\end{array}$ & $\begin{array}{l}36.0 \\
53.7 \\
58.5\end{array}$ & $\begin{array}{l}5.5 \\
8.2\end{array}$ & $\begin{array}{l}0.3 \\
0.5 \\
0.6\end{array}$ & 18.8 & $\begin{array}{r}7,400 \\
11,050 \\
12,030\end{array}$ \\
\hline A-65453 & $\begin{array}{l}\text { Pust bed, Pust mine, sec. } 28, T . \\
22 \text { N., R. } 55 \text { E., Richland Co. }\end{array}$ & $\begin{array}{l}\mathrm{A} \\
\mathrm{B} \\
\mathrm{C}\end{array}$ & $\begin{array}{r}38.3 \\
-\end{array}$ & $\begin{array}{l}25.4 \\
41.1 \\
45.6\end{array}$ & $\begin{array}{l}30.3 \\
49.2 \\
54.4\end{array}$ & $\begin{array}{l}6.0 \\
9.7\end{array}$ & $\begin{array}{l}0.5 \\
0.8 \\
0.9\end{array}$ & \begin{tabular}{l}
25.1 \\
\hdashline... \\
\hdashline..-
\end{tabular} & $\begin{array}{r}6,880 \\
11,140 \\
12,340\end{array}$ \\
\hline D-755\&0 & $\begin{array}{l}\text { Pust bed, Chimney Rock mine, } \\
\text { sec. 11, T. } 20 \text { N., R. } 56 \text { E., } \\
\text { Dawson Co. }\end{array}$ & $\begin{array}{l}\mathrm{A} \\
\mathrm{B}\end{array}$ & $\begin{array}{r}33.7 \\
\hdashline-1 .-2\end{array}$ & $\begin{array}{l}27.3 \\
41.1 \\
45.8\end{array}$ & $\begin{array}{l}52.2 \\
48.7 \\
54.2\end{array}$ & $\begin{array}{r}6.9 \\
10.2\end{array}$ & $\begin{array}{l}0.5 \\
0.7 \\
0.8\end{array}$ & 24.3 & $\begin{array}{r}7,090 \\
10,690 \\
11,910\end{array}$ \\
\hline D-75579 & $\begin{array}{l}\text { Unnamed bed,2 Albrecht mine, } \\
\text { sec. } 31 \text {, T. } 20 \text { N., R. } 54 \text { E., } \\
\text { Dawson Co. }\end{array}$ & $\begin{array}{l}\text { A } \\
\text { B } \\
\text { C }\end{array}$ & 36.3 & $\begin{array}{l}26.4 \\
41.5 \\
46.9\end{array}$ & $\begin{array}{l}29.9 \\
46.9 \\
53.1\end{array}$ & $\begin{array}{r}7.4 \\
11.6\end{array}$ & $\begin{array}{l}0.6 \\
0.9 \\
1.0\end{array}$ & 26.9 & $\begin{array}{r}6,780 \\
10,650 \\
12,040\end{array}$ \\
\hline A-3228 & $\begin{array}{l}\text { Unnamed bed,2 Chupp mine, } \\
\text { sec. 8, T. } 19 \text { N., R. } 55 \text { E., } \\
\text { Dawson Co. }\end{array}$ & $\begin{array}{l}\mathbf{A} \\
\mathbf{B}\end{array}$ & 38. 3 & $\begin{array}{l}24.4 \\
39.5 \\
44.7\end{array}$ & $\begin{array}{l}30.0 \\
48.7 \\
55.3\end{array}$ & $\begin{array}{r}7.3 \\
11.8\end{array}$ & $\begin{array}{l}0.3 \\
0.4 \\
0.5\end{array}$ & 32.0 & $\begin{array}{r}6,530 \\
10,590 \\
12,000\end{array}$ \\
\hline$A-34180$ & $\begin{array}{l}\text { Unnamed bed, } \text { Smith mine, }_{\text {T. }} \text {, } \mathbf{N} .55 \text { E., } 9 \text { miles NE } \\
\text { of Glendive, Dawson Co. }\end{array}$ & $\begin{array}{l}\mathbf{A} \\
\mathbf{B} \\
\mathbf{C}\end{array}$ & 32.6 & $\begin{array}{l}24.9 \\
37.0 \\
42.3\end{array}$ & $\begin{array}{l}34.0 \\
50.4 \\
57.7\end{array}$ & $\begin{array}{r}8.5 \\
12.6\end{array}$ & $\begin{array}{l}1.3 \\
1.9 \\
2.2\end{array}$ & 10.9 & $\begin{array}{r}7,380 \\
10.950 \\
12,520\end{array}$ \\
\hline 11045 & $\begin{array}{l}\text { Unnamed bed,3 Snyder mine, } \\
\text { sec. 2., } \\
\text { Dawson Co. }\end{array}$ & $\begin{array}{l}\mathbf{A} \\
\mathbf{B} \\
\mathbf{C}\end{array}$ & 32.1 & $\begin{array}{l}25.6 \\
37.7 \\
42.7\end{array}$ & $\begin{array}{l}34.2 \\
50.4 \\
57.3\end{array}$ & $\begin{array}{r}8.1 \\
11.9\end{array}$ & $\begin{array}{l}1.4 \\
2.0 \\
2.3\end{array}$ & 23.4 & $\begin{array}{r}7,110 \\
10,470 \\
11,890\end{array}$ \\
\hline
\end{tabular}

1 Forn:s of analysis are: A-as received; $\mathbf{B}$-moisture free; C-ash and moisture free.

3 This bed probably correlates with the B bed of the Sidney lignite field (Stebinger, 1912).

\section{PHYSICAL AND CHEMICAL CHARACTERISTICS}

Analyses of coal from eight mines in Richland County and northern Dawson County west of the Yellowstone River, including at least one in the vicinity of each deposit of strippable coal described in this report, are presented in table 3 . These samples show a calorific value 
of 6,530 to $7,400 \mathrm{Btu}$ for the lignite on an as-received basis-the equivalent of freshly mined lignite. . Reduced to a moist, mineral-matterfree basis, the heating values range from 7,100 to $8,150 \mathrm{Btu}$. Under the specifications of the American Society for Testing Materials (1939) which place the line dividing lignite from subbituminous coal at 8,300 Btu on the moist, mineral-matter-free basis, the coal in the area investigated is ranked as lignite, though some of it is not far below subbituminous coal in heating value. The ash and sulfur contents of the samples vary within narrow limits and are generally low. The ash is of medium fusibility, the softening temperature ranging from $2,330^{\circ} \mathrm{F}$. to $2,460^{\circ} \mathrm{F}$. Being more reactive than coals of higher rank, the lignite is well adapted to the manufacture of synthetic liquid fuels.

On fresh exposures the lignite is a tough, black to brownish-black coal. Where it is scratched, the resulting streak is brown. The lignite has a subconchoidal fracture and resists fracturing more strongly than the higher rank coals so that it tends to break out in large irregular slabs when mined. On fresh cross sections it is seen to be predominantly dull attrital coal banded with lenses and layers of bright coal, or previtrain. The bright layers are usually 2 to 3 inches thick but in places are as much as 8 inches. Frequently the woody texture of the original material is preserved in the lignite, and the outline of knots, limbs, and even whole logs can be observed. The lignite is relatively nonfriable and thus resists degradation in size better than do the higher rank coals (Corps of Engineers, 1948, p. 23). In some places the cross section also shows thin partings of clay and zones of bone or carbonaceous shale. Other visible impurities are pyrite, which occurs either in fine disseminations or as fracture fillings, and gypsum, which is found as fracture fillings near the tops of the beds.

An important characteristic of lignite is its tendency to lose moisture, slack, and ignite spontaneously when exposed to air. This characteristic of lignite presents serious storage and shipping problems, but these problems can be solved by taking special precautions. Perhaps the most widely accepted method is to store the fuel in compacted piles; lignite so stored has resisted slacking for years. Other methods that have been used successfully are storing under water, storing in pits, and capping storage piles with an airtight cover such as road tar.

\section{CLINKER AND ITS RELATION TO LIGNITE}

The thick beds of lignite in the Tongue River member of the Fort Union formation are commonly burned along the outcrop and for some distance beneath the overlying rocks. This burning has resulted in the formation of abundant, conspicuous masses of clinker, or as it is called locally, scoria. Clinker or scoria is a general term that includes all the types of rock produced in the melting and baking 
of sandstone and shale by the intense heat of the gases rising from the burning lignite beds. The melted rock, which resembles volcanic lava, has a slaggy, vesicular structure and a vitreous texture. The baked rock, on the other hand, usually retains its original texture and bedding, but the individual grains are fused together. Rogers (1917, p. 1-10) has described in detail the physical and mineralogic changes that occur during the melting and baking. The dominant color of large masses of clinker is a brick red. Because clinker is much more resistant to erosion than the unaltered rocks in this area, it forms the cap rock of many buttes and benches.

The largest masses of clinker are usually associated with thick lignite beds, but bed thickness alone does not govern the extent of clinkering. Because the burning of lignite depends upon the supply of air, the distance a bed will burn behind its outcrop depends largely on the amount of cover. In areas of thin overburden, the slumping caused by the burning out of the lignite opens fissures that permit the circulation of air; and, in such areas, lignite beds have burned for more than a mile underground. The heat from a burning lignite bed has. little or no effect on the underlying rocks, but the overlying rocks may be clinkered for as much as 100 feet above the original base of the lignite bed.

The areas that are underlain by clinker have been shown on the maps of the strippable lignite deposits (pls. 46-48) with a distinctive symbol. The dotted line enclosing the area of clinker represents theapproximate location of the underground contact between clinker and. unburned lignite.

\section{PRINCIPAL LIGNITE BEDS}

Of the many lignite beds in the Sidney, Glendive, and RicheyLambert coal fields (see fig. 41), only two are of importance in this investigation: The "lowest minable bed" of the Glendive lignite field (Hance, 1912) and the Pust bed of the Richey-Lambert coal field. (Parker, 1936). The others are either too thin for economical development or do not crop out in areas suitable for strip mining. The G bed of the Sidney lignite field, for example, is very persistent on the east side of the Yellowstone River, but no trace of its outcrop could: be found on the gravel-covered slopes of the west side of the Yellowstone in the investigated area. Well logs in secs. 30, 31, and 32, T. 20 N., R. 57 E., however, indicate the presence of the G bed about 70: feet below the Pust bed. As the wells penetrated no more than 4 feet. into the $\mathrm{G}$ bed, the thickness is not known.

"Lowiest minable bed" of the Glendive lignite field.-The lowest minable bed of the Glendive lignite field is actually not one bed but two beds about 50 feet apart. Hance (1912, p. 273) mapped the lower bed. 


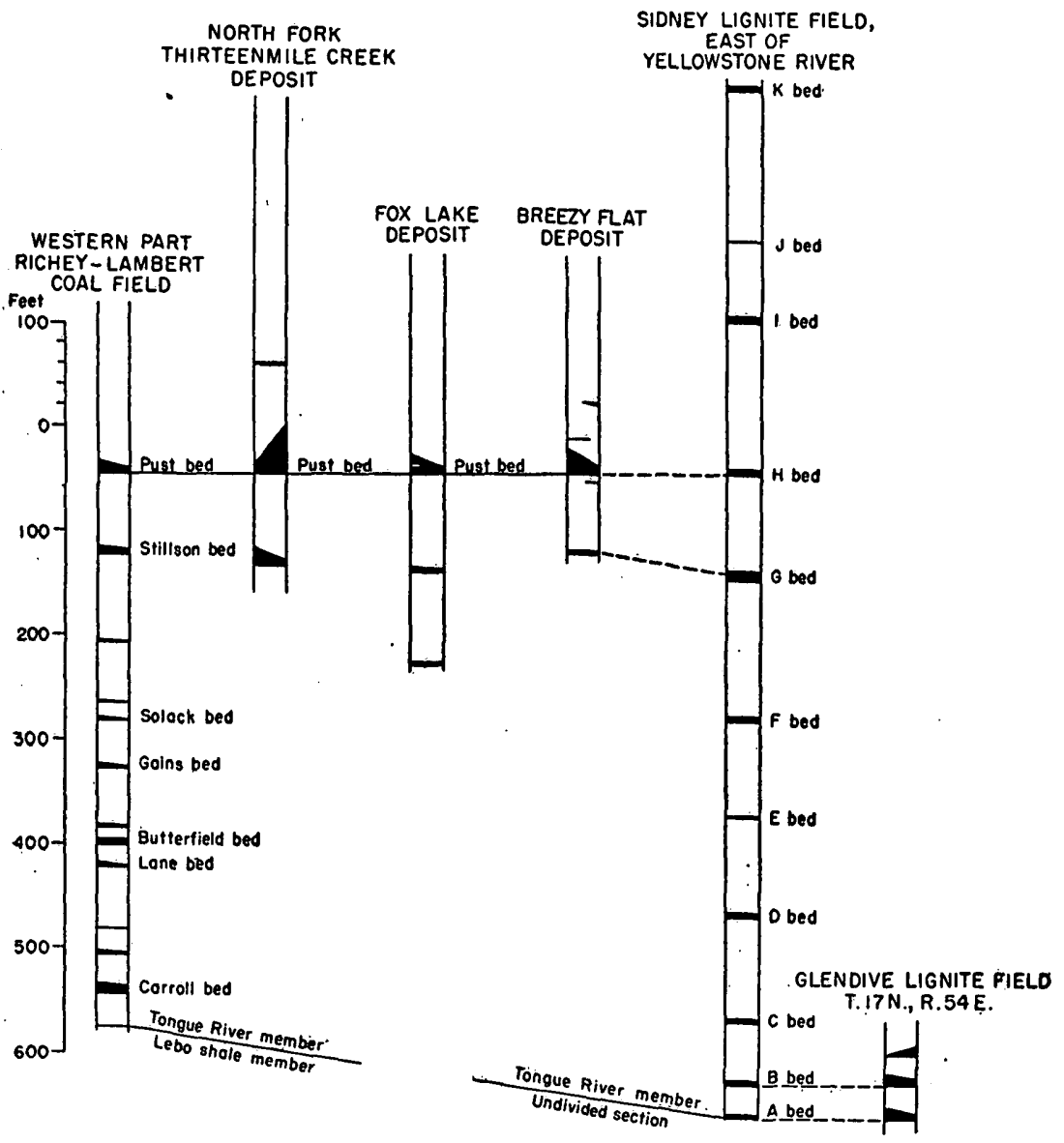

FigORE 41.-Generalized columnar sections in southern Richland County and northern Dawson County, Mont., showing correlatious of lignite beds in the Fort Union formation.

only where he thought that it was thick enough to be minable; otherwise, he carried the traverse to the second bed. The two beds undoubtedly correspond to beds $\mathrm{A}$ and $\mathrm{B}$ of the Sidney lignite field (Stebinger, 1912).

The lowest bed and its equivalent, the $\mathrm{A}$ bed, crop out at the southern tip of the area and can be traced as far north as the town of Intake where the northeastward dip of the bed carries it beneath the surface of the Yellowstone River. The bed ranges in thickness from 2 to 10 feet, attaining the maximum thickness in the vicinity of Deer Creek. It is usually free of partings, but in sec. 32 , T. 17 N., R. 54 E., the upper 3 feet is bony. The local mines which supply the town of Glendive take their coal from this bed or the one above it, and there are numerous prospects indicating that the beds were the source of fuel for the early settlers of this region. 
Pust lignite bed.-By far the thickest and most continuous of the lignite beds in this area is the Pust bed of the Richey-Lambert coal field (Parker, 1936). The measured thickness of the lignite ranges from a few inches to 43 feet (fig. 44, no. 10); thicknesses exceeding 25 feet are not uncommon.

In the Richey-Lambert field the Pust bed crops out in the southeast part of T. 21 N., R. 52 E., and can be traced northeast along the west side of the Missouri River-Yellowstone River divide to the vicinity of Lambert, where it pinches out to the north and east. To the south, however, the outcrop continues down the valley of the North Fork of Burns Creek and is marked on both sides of the valley by large thicknesses of clinker. The writer traced the bed southward down Burns Creek from the southern boundary of the Richey-Lambert field and found that it corresponded to the lignite bed of the Breezy Flat strippable deposit (pl. 48), which Stebinger (1912, p. 310) called the $G$ bed of the Sidney lignite field. However, from his detailed observations in the vicinity of the Breezy Flat deposit, the writer believes that this correlation is erroneous and that the lignite bed of the Breezy Flat deposit is the same bed that Stebinger (1912, p. 314) calls the $\mathbf{H}$ bed in T. 21 N., R. 58 E. This opinion is also held by Prichard (oral communication). The Pust bed would thus be correlated with the $\mathrm{H}$ bed of the Sidney lignite field.

Further reconnaissance investigations by the writer in the area south of the Richey-Lambert field (see fig. 40) indicate that the outcrop of the Pust bed extends southeastward along the east side of the valley of North Fork of Thirteenmile Creek to about T. 19 N., R. $56 \mathrm{E}$., where it curves around to the north and extends up the valleys of the South, Middle and North Forks of Burns Creek. Along most of its entire length, the outcrop is marked by thick masses of clinker, which indicate that the bed that formed it was also thick. This indication is corroborated by a report of a thickness of 30 feet in sec. 8, T. 19 N., R. 55 E. (Bureau of Mines, 1932, p. 87) ; a reported thickness of 45 feet, measured by hand auger in sec. 16, T. 20 N., R. 56 E., and the thickness of more than 25 feet at the Chimney Rock mine in sec. 11, T. 20 N., R. 56 E. (See pl. 45-B.) The Pust bed, thus, probably underlies an area of about 300 square miles between the North Fork of Thirteenmile Creek and the North Fork of Burns Creek.

All three of the deposits described in this report are contained in the Pust lignite bed, which is about 525 feet above the base of the Tongue River member in the Richey-Lambert coal field:

\section{UTILIZATION OF THE LIGNITE}

The local demand for coal in eastern Montana is small. Coal was the only fuel available to the early settlers of Montana, but nat- 


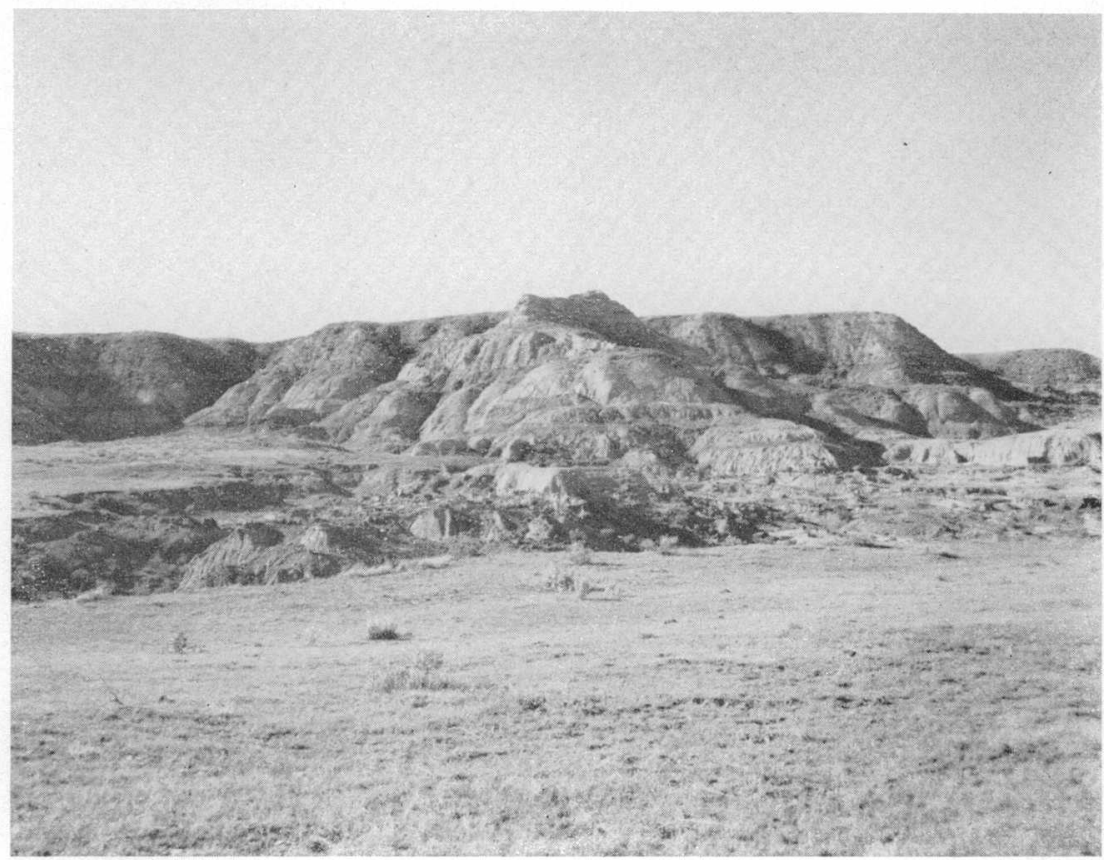

EXPOSURE OF UPPER PART OF UNDIVIDED SECTION. 


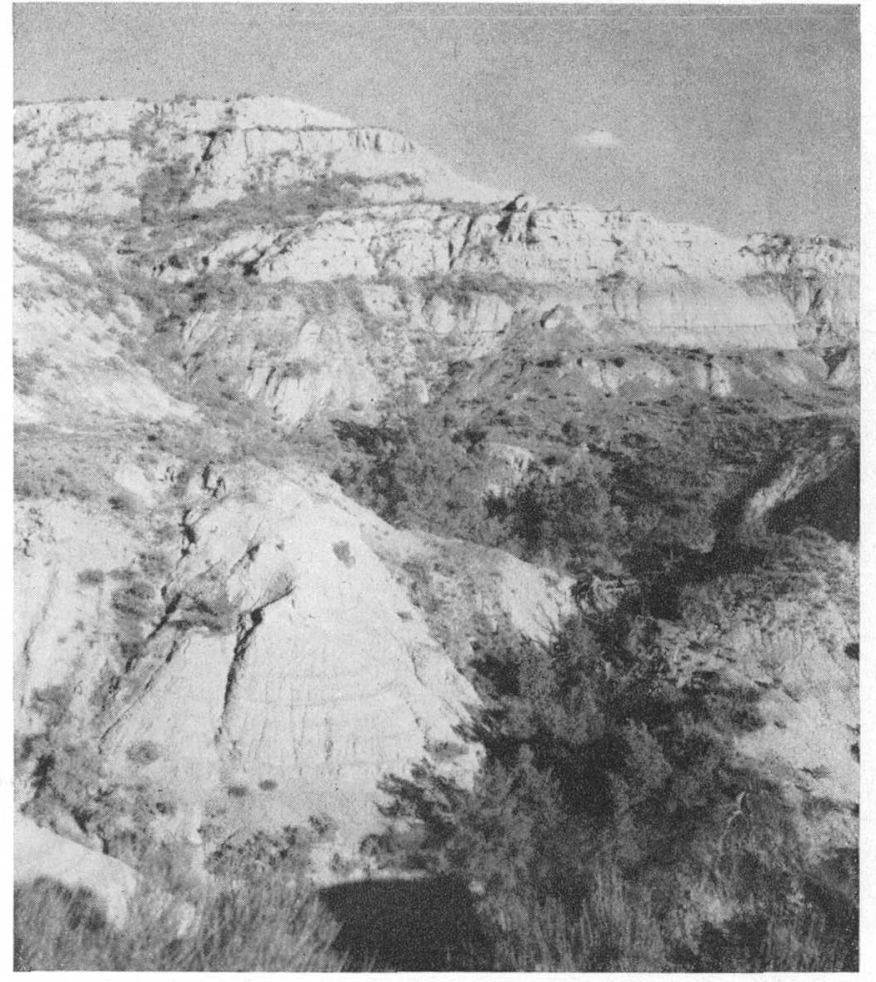

A. EXPOSURE OF TONGUE RIVER MEMBER IN BADLANDS.

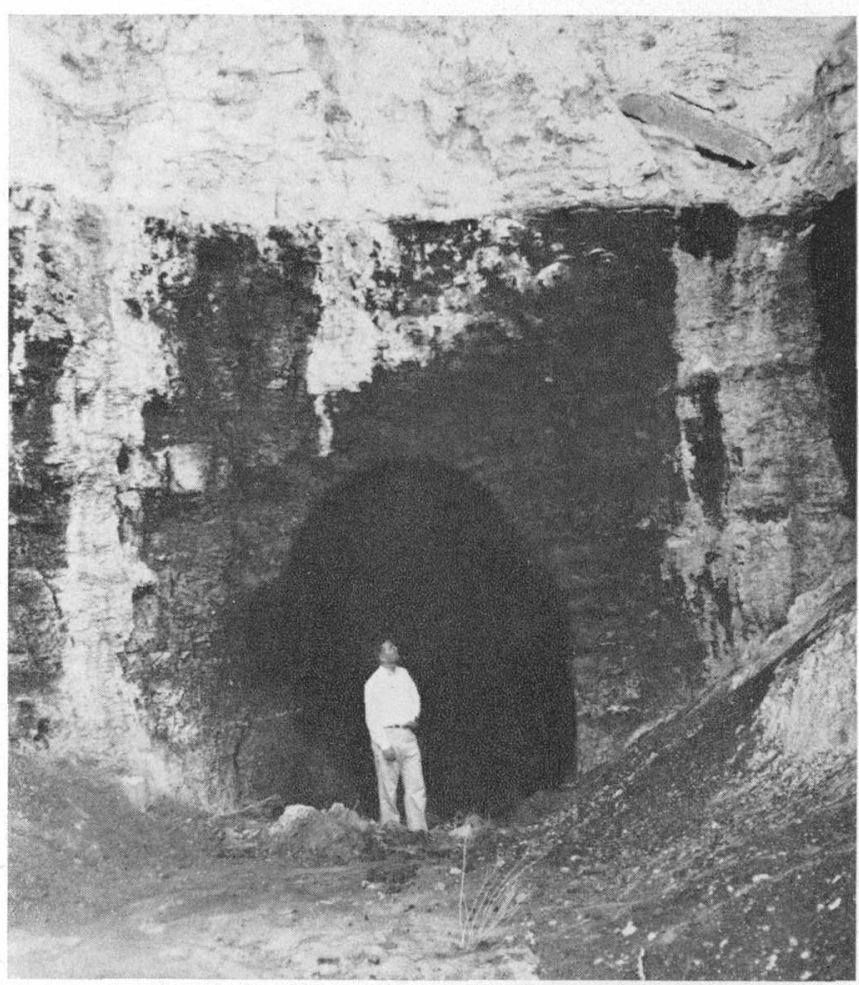

B. EXPOSURE OF THE UPPER PART OF THE PUST LIGNITE BED AT THE ENTRANCE TO THE CHIMNEY ROCK MINE. 
ural gas has since entered the field and is now a strong competitor of coal in the domestic market. Most of the coal now mined in eastern Montana is used as locomotive fuel; however, oil is replacing coal in this market.

Increased local demand for coal in the future is dependent upon industrialization of the eastern Montana area. As industries need large supplies of power; it would be necessary to supplement the existing hydroelectric plants with steam electric plants for which the low rank coal in this area would be the most suitable fuel. Another possible use is for the production of synthetic liquid fuels, lignite being particularly well suited to the hydrogenation process for producing these fuels. The number of synthetic liquid fuel plants in this area would be limited; however, by the searcity of water; for the minimum water requirement of a typical hydrogenation plant having a daily output of 10,000 barrels of fuel is more than 7 million gallons per day (Corps of Engineers, 1948, p. 36). The only nearby source of a steady supply of water in such quantities is the Yellowstone River. The utilization of lignite for the production of other types of hydrocarbons and related chemicals is the subject of considerable study and research at the present time and gives promise of being commercially practicable in the near future.

A potential market for the coal from this area is in the Pacific Northwest. The rapid increase in the industrialization of the States. of Oregon and Washington calls for a corresponding increase in their imports of coal, as local supplies of coal and other fuels are inadequate for the industrial and domestic needs of the area. Eastern Montana: could supply much of this demand, because it not only contains an abundant supply of coal that can be mined cheaply but has excellent rail connections with the Pacific Northwest. These facts largely. compensate for the low rank and consequent low heating value of the coal and for the shipping and storage problems springing from its: tendency to slack and burn spontaneously.

\section{SCOPE AND METHOD OF INVESTIGATION}

The purpose of this investigation was to find large deposits of lignite that could be mined by large-scale, strip-mining methods, to estimate the reserves of lignite in each deposit, and to provide basic data on the depth and nature of overburden, and other factors that influence the economic mining of the deposit. The three deposits: described in this report thus do not by any means exhaust the places in southern Richland County and northern Dawson County where lignite could be strip mined economically but include only the larger and better located deposits where sufficient information was obtained : to fulfill the above requirements. The standards used in selecting: 
these deposits, though of necessity somewhat arbitrary, are based on advanced stripping practices of the present day with allowance for probable advances in the future.

\section{STANDARDS OF SELECTION}

Of the many economic factors that influence strip mining of coal, the most important in the area under discussion are: (1) The thickness of the coal; (2) the thickness and nature of the overburden; (3) the nature of the terrain; (4) the quality of the coal, with particular reference to the number, thickness, and nature of partings; (5) the dip of the beds; (6) the stripping ratio, or relationship between the volume of the coal mined and that of the overburden removed, and (7) the total reserves.

Thickness of the coal.-The minimum thickness of coal that can be mined profitably by surface methods depends on local conditions. In some of the bituminous coal fields of Missouri and Kansas, beds as thin as 1 foot have been mined at a profit. In North Dakota, however, where the coal is lignite in rank, the minimum thickness of beds now being recovered by stripping is about 5 feet. The 5 -foot thickness of coal is also the average for strip mines operating in the United States in 1950 as reported to the Bureau of Mines (Young, 1952). This minimum thickness was adopted for this investigation, partly because of present practice in North Dakota where the lignite is of comparable grade and partly because the 5-foot thickness is used in coal reserve estimates as the dividing line between intermediate and thin lignite or subbituminous coal (Averitt and Berryhill, 1950, p. 9).

It is obvious that for economic recovery a strippable coal bed should be as thick as possible. In the area under investigation there is so much thick lignite that it appears likely that beds less than 10 feet thick will not be exploited in the foreseeable future. For that reason the average thickness of the deposits described in this report is at least 10 feet, or twice the minimum thickness specified above.

Thickness and nature of overburden.-The thickness of overburden that can be economically removed from the bed of lignite depends largely on the type and capacity of the earth-moving equipment used. The average thickness of overburden in all coal strip mines of the United States in 1950 was 39 feet (Young, 1952). A large part of the equipment now in use can remove as much as 60 feet of cover; and, in some parts of the country, that figure is considered as a rough maximum for strip mining. At the Colstrip mine in Rosebud County, Mont., however, a maximum of 125 feet of overburden is removed from a 28-foot bed of coal, the average thickness being about 80 feet. For the purposes of this report, the maximum thickness of cover is taken to be 120 feet, and on the deposit maps the overburden is broken 
down into three thickness ranges: Less than 60 feet, 60 to 90 feet, and 90 to 120 feet.

Throughout the area covered by this investigation, the overburden rocks are poorly consolidated sandstones and shales that are easily removed after light blasting, and thus present no serious mining problems.

Nature of the terrain.-Intensively dissected areas are not as a rule recommended for stripping, although the disadvantages of rough terrain may be offset by advantages of other kinds. Particularly bad for stripping are steep slopes, where the overburden limit line is likely to be so close to the coal outcrop that only a narrow strip of coal can be recovered.

Quality of the coal. -The quality of the coal, which is governed largely by the number, thickness, and nature of the partings of bone, shale, or other impurities it contains, affects the minability of lignite differently from that of bituminous coal. In the case of the higher rank fuel, it is possible to mine the entire bed without regard to the partings and remove the impurities at the cleaning plant; the cost of cleaning, with a relatively high-priced fuel, is less than that of selective mining. The relatively low price at which lignite must be sold, coupled in many instances with rather long freight hauls, makes it imperative that lignite be mined as cheaply as possible and, usually, marketed without cleaning. Further, because of their woody structure, lignites cannot be cleaned satisfactorily by the methods used for higher rank coals. It follows that lignite cleaning plants are rare at present, and special efforts are made to mine the fuel where it is relatively free from partings. In practice, one or two 1-inch partings in a thick bed do not increase the ash content sufficiently to be a major factor; and usually, as at the Colstrip mine, no attempt is made to remove them. Partings ranging in thickness from a few inches up to 2 or 3 feet are usually scraped off and discarded if the underlying part of the bed is thick enough to warrant the small extra expense (Nugent, oral communication). For the purposes of this investigation, numerous thin partings or more than one thick parting are considered to make a lignite bed unfit for strip mining.

Dip of beds.-In most of the coal fields of the United States, particularly in those containing low-rank coal, it is generally considered that coal beds dipping $20^{\circ}$ or more cannot be profitably strip mined. This limitation is of no practical importance in the area investigated, because the dip of the beds is usually less than $1^{\circ}$; for mining purposes they may be considered as flat-lying.

Stripping ratio.-No effort was made to set up a maximum stripping ratio because the figures for the area investigated are very low as compared with the National average, much less the average maximum. 
The average ratio of thickness of overburden to thickness of coal for strip mines operating in the United States in 1950 was 8:1 (Young, 1952).

Total reserves.-To be suitable for a large scale operation, a strippable deposit should contain sufficient reserves to insure continuous operations for at least 5 years, as it would not be profitable to move heavy stripping equipment into an area for a shorter period. Based on the anticipated scale of future operations in southeastern Montana, the minimum reserve of coal should be at least 15 million tons. All of the deposits described in this report are much larger than this minimum.

\section{PRELIMINARY INVESTIGATION}

The first step in the investigation west of the Yellowstone River in southern Richland County and northern Dawson County was a study of the published reports to locate the areas in which the lignite was thick and free of partings. After this was done, a reconnaissance trip was made through the area, and water-well drillers, miners, and ranchers were interviewed to obtain additional information on the thick beds of lignite, particularly those not well exposed at the surface and to note the areas in which the topography was favorable for largescale strip deposits. All the information was then assembled and analyzed for the purpose of selecting areas for detailed investigation.

\section{DETAILED INVESTIGATION}

The next steps in the investigation were to determine the thickness of the strippable lignite in the selected deposits, to plot the outcrop and thickness-of-overburden lines on aerial photographs, and finally to transfer all the information to maps prepared from the photographs so that the reserves of lignite and the stripping ratio could be estimated.

Determination of the thickness of the strippable lignite.-The estimates of the average thickness of lignite in the various strip deposits (table 1) are based on six types of thickness. information: (1) Exposures measured by the writer, (2) exposures reported in the coal field bulletins of the U. S. Geological Survey, (3) thicknesses obtained by a power auger operated by the U. S. Geological Survey, (4) thicknesses obtained by water-well drillers, (5) reports of such thicknesses, and (6) thicknesses obtained by seismograph shot-hole drilling. The location of the thickness information is shown on the deposit maps (pls. 46-48). On illustrations accompanying the deposit maps (figs. :42, 44, 46), graphic sections show the thickness of the lignite bed and of partings, the depth to the top of the lignite where the section was measured by drilling, and the source of the thickness information. 
Figures 43,45 , and 47 show the distribution of the thickness of the lignite bed in each of the deposits.

The surface exposures of the lignite bed are the most reliable measurements of thickness and may be considered accurate. Next in reliability are thicknesses obtained by power-auger drilling. The auger gives good recovery of cuttings in holes less than 50 feet deep; and, in exceptionally favorable localities, in holes 65 feet deep. It is usually possible to locate the top and bottom of the lignite beds within a foot or two and to recognize clay partings more than 2 or 3 inches thick. In some holes, particularly those that penetrated the water table, only enough cuttings reached the surface to confirm the presence or absence of the lignite; but, even in those circumstances, it was possible for an experienced driller to tell, from his knowledge of the drilling characteristics of lignite and of various types of rock, the approximate thickness of the bed. Thus, the data obtained from power-auger holes may be considered reliable within rather narrow limits.

Thickness information obtained from water-well drillers, although often accurate within 1 to 3 feet, is usually less reliable than those of auger holes primarily because the logs are not kept in any standard manner and because most water-well drillers are interested only slightly in the depth and thickness of the lignite beds they penetrate. Reports of such thicknesses from local residents are, in addition, subject to the errors of memory where the water-well logs were not recorded at the time of drilling. Because of these factors, water well thicknesses were corroborated wherever possible with power-auger holes or measurements at surface exposures.

Information obtained from seismograph shot-hole logs are usually the least reliable. Shot-hole drillers are capable of determining the thickness of the lignite within two or three feet, but here again the driller is interested only slightly in the depth and thickness of the lignite and thus usually does not expend the extra effort that is needed to measure and record these thicknesses accurately. Shot-hole information was used in determining average thicknesses only when corroborated by nearby power-auger holes or exposures.

Plotting of outcrop and overburden lines.-Aerial photographs on a scale of 1:20,000 were used as base maps for the plotting of outcrop and overburden lines. The outcrop line of the strippable lignite bed was drawn on these photographs in the field, using as guides the existing geologic maps of the coal fields. The dip of the coal bed was established by a traverse of all the points where the position of the lignite bed was known. These traverses were run by reconnaissance methods, using either a surveying altimeter or plane table and alidade. The 60-foot, 90-foot, and 120-foot overburden lines (contour lines 
which show the thickness of the overburden on the lignite bed) were then drawn either by reference to points where the thickness of overburden was known or by reference to control points established for this purpose. The thickness of overburden at the control points was determined by calculations involving the dip of the lignite bed and the height of the control point above the nearest exposure or drilled section. The differences of elevation were determined with the altimeter or alidade, or, where short distances were involved, by the hand level.

Because of the scattered nature of the bed information and the reconnaissance method of mapping, the overburden lines are of necessity somewhat generalized. It is assumed, however, that before actual operations are begun in any deposit it will be mapped and drilled in sufficient detail to permit accurate calculations of the stripping ratio and the total yardage of overburden, as well as the thickness and tonnage of lignite.

Estimation of reserves.-After the field mapping was completed, the data on the aerial photographs were transferred to the final deposit map by use of the radial line assembly method. From this map and from a distribution-of-thickness map drawn up from the lignite thickness information the reserves of strippable lignite were calculated. First, the average thickness of the lignite in each deposit was estimated from the distribution-of-thickness map. Next, the acreage in the less than 60 -foot, 60 to 90 -foot, and 90 to 120 -foot overburden subdivisions of each deposit were measured with a planimeter. The acreage was then multiplied by the average thickness to obtain the volume of lignite in acre-feet; the volume, in turn, was multiplied by the weight of lignite per acre-foot to get total original reserves in short tons. As precise data on the weight of this lignite were not available, it was assumed to be the same as the nationwide average of 1,750 short tons per acre-foot (Averitt and Berryhill, 1950, p. 11).

Because the amount of coal taken from the ground in the mapped deposits prior to January 1, 1952, is so small as to be insignificant, the original reserves as calculated above can be considered to be equivalent to the remaining reserves in the ground as of that date. The percentage of remaining reserves that is recoverable by surface-mining methods depends on so many factors, physical and economic, that it cannot be determined until the properties are surveyed in much more detail than was practicable for the present investigation. As a matter of general information, however, it may be stated that the recovery of coal and lignite in large strip mines is usually considered to be from 80 to 90 percent of the coal originally in the ground. As the strippable deposits described in this report are considerably better 
than the average, it may be assumed that a recovery of 85 to 90 percent may reasonably be expected with modern mining methods.

The reserves in each deposit are tabulated in table 1 under four headings: Lignite under less than 60 feet of cover, that under 60 to 90 feet of cover, that under 90 to 120 feet, and total reserves. In this table both the acreage and the reserves of lignite in each depth category are given.

The reliability of the reserve calculations can be inferred from the distribution of the thickness data and from the known persistence of the bed of strippable lignite. All of the strippable lignite is within $1 \frac{1}{4}$ miles of a point where the thickness of the bed was measured or reported and 90 percent of it is within 1 mile. As the bed of strippable lignite, the Pust bed, is known to be persistent for miles along its outcrop, it may fairly be assumed to be persistent for long distances back from the outcrop. Thus, the spacing of the thickness data gives a fairly reliable picture of the average thickness of the strippable lignite. The estimates therefore fall into the "indicated" category of the reliability classification, as defined by Averitt and Berryhill (1950, p. 11).

Estimation of stripping ratio.-Stripping ratio is defined as the ratio between the amount of overburden removed from a coal bed and the amount of coal uncovered by this operation. Two types of stripping ratio are in common use at present; one is the ratio between thickness of overburden and thickness of coal, expressed in feet of overburden per foot of coal; the second is the ratio of the volume of overburden to the weight of coal, expressed in cubic yards of overburden per ton of coal. For lignite, these two ratios are nearly equalthe thickness to thickness ratio equals 1.1 times the volume to weight ratio. The latter ratio is used in this report because it is given in terms of cubic yards, the unit in which the capacity of stripping shovels is measured; and in tons, the unit in which coal is sold. In calculating this ratio the average thickness of the overburden in each of the less than 60 -foot, 60 - to 90 -foot, and 90 - to 120 -foot thicknessof-overburden subdivisions of the deposit was estimated. This average thickness of each subdivision, in yards, was multiplied by the area of that subdivision in square yards, to obtain the volume of overburden in cubic yards. The volume divided by the weight of coal in tons gave the average stripping ratio for each subdivision in cubic yards of overburden per ton of coal. To obtain a weighted average ratio for the entire deposit, each subdivision ratio was multiplied by the area of that subdivision, and the sum of these products was then divided by the total area. The average stripping ratio figures, as given in the deposit descriptions below, are considered to be accurate within 20 percent. 


\section{SELECTED DEPOSITS OF STRIPPABLE LIGNITE}

\section{FOX LAKE DEPOSIT}

The smallest of the three strippable deposits described in this report is the Fox Lake deposit (see pl. 46), in secs. 13, 14, 15, 22, 23, and 24, T. 22 N., R. 54 E., and secs. 16, 17, 18, 19, 20, and 30, T. 22 N., R. 55 E., Richland County, Mont. It is about 31 road-miles north of Intake and about 32 road-miles west of Sidney by way of gravel- or clinker-surfaced county roads. The road from Sidney is the better of the two approaches. The eastern part of the deposit lies about two miles southwest of the town of Lambert and about 1 mile south of the branch line of the Great Northern Railway, that passes through Sidney and joins the main line at Snowden, Mont. The roads in the deposit area are poor and are usually impassable during heavy rains or when snow-covered. During good weather, however, nearly all parts of the deposit can be reached by a good field car. The deposit is part of the Richey-Lambert coal field (Parker, 1936).

Topography and land use.-The eastern part of the deposit is a low, rounded ridge which separates the drainage of two branches of the South Fork of Fox Creek. The western part underlies the north slope of a ridge that separates the drainage of North Fork of Burns. Creek from that of the South Fork of Fox Creek. The north slope has a rolling surface that is dissected by a few small gullies; the south slope, on the other hand, is a rough, highly dissected surface of the badlands type of topography. Because of the rough terrain, the lignite underlying the south slope was not mapped as a part of the deposit.

The average elevation of the area is 2,650 feet above sea level; the relief is about 150 feet. About 80 percent of the area is grass-covered and is used for raising cattle; wheat and corn are planted in the remainder.

Pust. lignite bed.-The strippable lignite in this deposit is in the Pust bed. The eight measurements of the thickness of the bed shown in figure 42 were drilled by power auger, measured by Parker (1936, p. 167, 172), or reported on an abandoned mine. They show that the bed usually contains at least one parting which is thick enough at the east and west ends of the deposit to divide the bed into two benches. Exclusive of partings, the thickness of the lignite ranges from 7 to. 17 feet and averages about 11 feet. The distribution of the thickness. of the bed is shown in figure 43 .

The best exposure of this bed is at an operating underground mineat the common quarter corner of secs. 28 and 33, T. 22 N., R. 55 E. An analysis of the lignite from this mine is given in table 3 (Laboratory no. A-65453). 

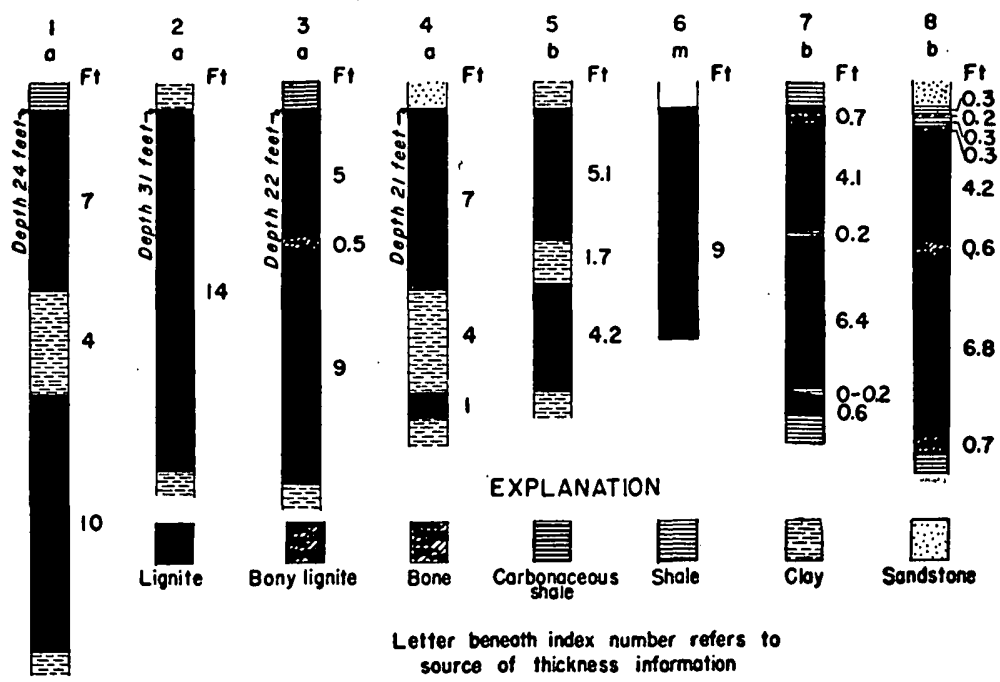

\section{Letter beneoth index number refers to} source of thickness informotion

Figure 42.-Sections of Pust lignite bed in and near Fox Lake strippable deposit. a, Indicates power auger; b, bulletin of the U. S. Geological Survey; m, mine or project report.

Draining the strip pits in this deposit should not be a problem, because there is very little water in the lignite bed. The Pust bed dips about 20-30 feet per mile; the dip is eastward in the western part of the deposit and northward in the eastern part.

Overburden and floor rock.-The overburden above the Pust bed is predominantly massive, friable, fine- to medium-grained sandstone interbedded with poorly indurated shale. The floor rock is a soft, gray clay.

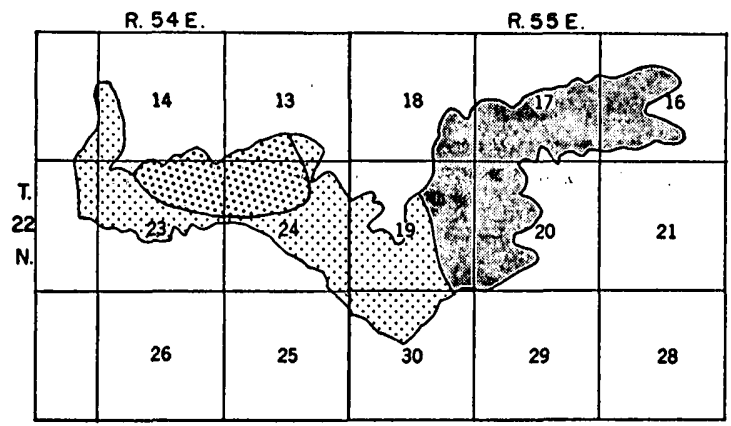

EXPLANATION

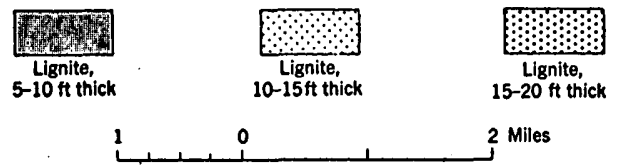

Figurn 43.-Map showing distribution of thickness of the Pust lignite bed, exclusive of partings, in Fox Lake strippable deposit. 
Reserves and stripping ratio.-The original reserves of strippable lignite in the Fox Lake deposit total 46.3 million tons. About 80 percent of this amount, or 36.2 million tons, is under less than 60 feet of overburden. The 36.2 million tons of lignite could be uncovered at an average stripping ratio of about 3 cubic yards of overburden per ton of lignite; the total amount at a ratio of nearly 4 yards of overburden per ton of lignite.

Possible extensions of the deposit.-The only practical direction in which this deposit might be extended is westward. Two measurements in sec. 19, T. 22 N., R. 54 E. (Parker, 1936, p. 167) indicate that the Pust bed probably maintains an average thickness of about 10 feet for several miles westward from the western boundary of the Fox Lake deposit. The strippable part of the bed-the part under less than 120 feet of overburden-extends westward in a strip a quarter to half a mile wide under the north slope of the Redwater Creek-North Fork Burns Creek divide. However, as this slope is more dissected than that overlying the main part of the deposit and as the outline is more sinuous, this area is not considered to be as favorable for stripping as the Fox Lake deposit.

\section{NORTH FORK THIRTEENMILE CREEK DEPOSIT}

The North Fork Thirteenmile Creek deposit (pl. 47) contains large reserves of thick lignite that can be recovered at a very low stripping ratio. The deposit is in secs. $27,28,29,32,33,34$, and 35, T. 21 N., R. 53 E.; secs. 1, 2, 3, 11, and 12, T. 20 N., R. 53 E.; and secs. 4, 5, 6, 7, 8, and 9, T. 20 N., R. 54 E., Dawson County, Mont. It is 15 road-miles southeast of Richey, the terminal of a branch line of the Great Northern Railway, and 36 road-miles north of Glendive, the nearest town on the Yellowstone River. The main Glendive-Richey road, which is gravel-surfaced, passes through the center of the deposit. Secondary roads on nearly every section line provide easy access to all parts of the deposit.

The northern part of the area, T. 21 N., R. 54 E., is part of the RicheyLambert coal field (Parker, 1936). No previous reports are available for the southern part.

Topography and land use.-The deposit underlies a wide, shallow valley that has been cut from a broad upland surface called the Retah Table. The sides of the valley fall away steeply from the tableland and are generally dissected by deep gullies. The valley floor, however, is nearly level except for a few small hills and ridges 40 to 75 feet high. The average elevation of the area is about 2,700 feet above sea level. The North Fork of Thirteenmile Creek, an intermittent stream, drains all parts of the deposit. 
Wheat and other small grains are planted in about one-third of the land; the remainder is grass covered and used for pasture.

Pust lignite bed.-The lignite of the North Fork Thirteenmile Creek deposit is in the Pust bed. The top part of the bed is well exposed at several abandoned mines (pl. 47 locations 6, 7, and 9), but is somewhat weathered. The nearest fresh exposure is at the Albrecht mine, sec. 31 , T. 20 N., R. 54 E., where the upper bench of a bed, which is apparently the Pust bed, is being strip mined. A sample from this mine was analyzed by the U.S. Bureau of Mines in 1951. (See table 3, no. D-75579.)

Because of the lack of exposures at. which the entire thickness of the bed could be measured, the thickness of the Pust bed was determined primarily from power-auger holes and from reports of lignite measured in water wells. (See fig. 44.). The logs of seismograph shot holes that showed the thickness of the bed were also available to the writer; but, because of the confidential nature of their location, they are not given in the graphic sections of the lignite in figure 44. They were, however, used in determining the distribution of thickness of the bed as shown in figure 45 . The bed ranges in thickness from 10 to 43 feet, probably averages about 25 feet thick, and is generally free of partings.

Two farmers in this area seport that a lignite bed, probably a lower bench of the Pust bed, underlies the area west of the north fork of Thirteenmile Creek. In the SW1/4 of sec. 6 , several wells penetrated 1 to 2 feet into a bed of hard lignite at depths ranging from 29 to 33 feet. In the $S W 1 / 4$ sec. 7, lignite was encountered at depths ranging from 9 to 15 . feet in exacavations and wells directly beneath the terrace gravel deposit that covers this part of the area. The thickness of the bed was not determined; further drilling, however, may show that it is of minable thickness.

The water table in the northern part of the deposit is found at, or just below, the base of Pust lignite. In the southern part of the deposit, however, water is usually encountered at the top of the bed or in the sands above it. As the dip of the bed is about 30 to 40 feet per mile eastward, strip pits could probably be made self-draining in the western half of the deposit. Pumping would probably be necessary in the eastern half, because the dip of the bed is opposed to the slope of the land.

Overburdien and floor rock.-The overburden of the Pust bed consists predominantly of friable, fine- to medium-grained-sandstone interbedded with soft, gray shales and one or two thin lenticular beds of lignite. A deposit of terrace gravel, 5 to 15 feet thick, underlies the surface in half a mile wide strip along the west bank of the North Fork Thirteenmile Creek in the southern half of the deposit. At 

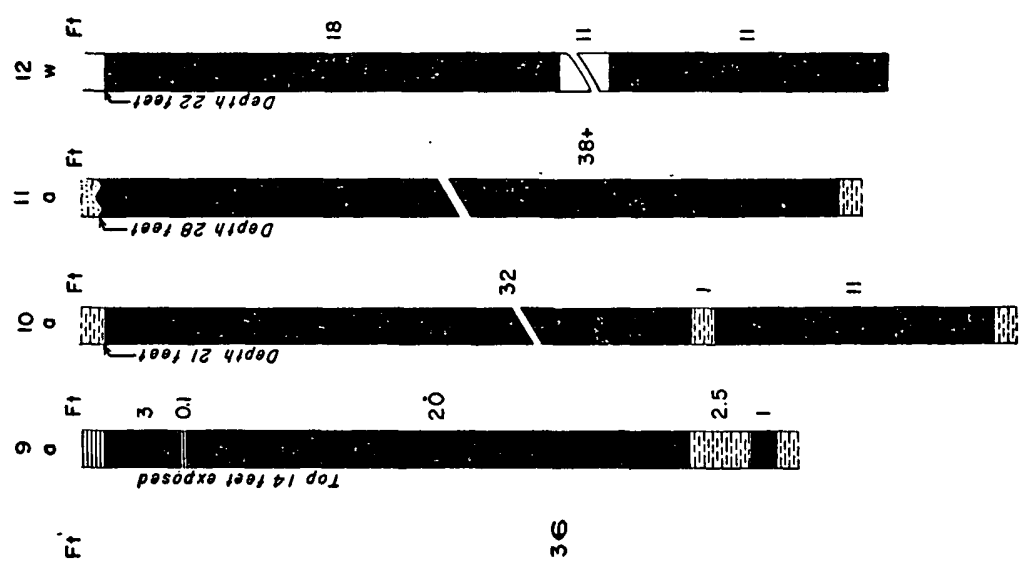

$\infty 3$

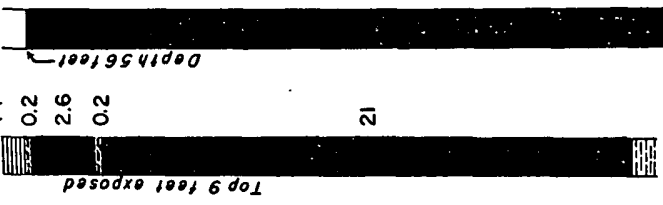

E.

N
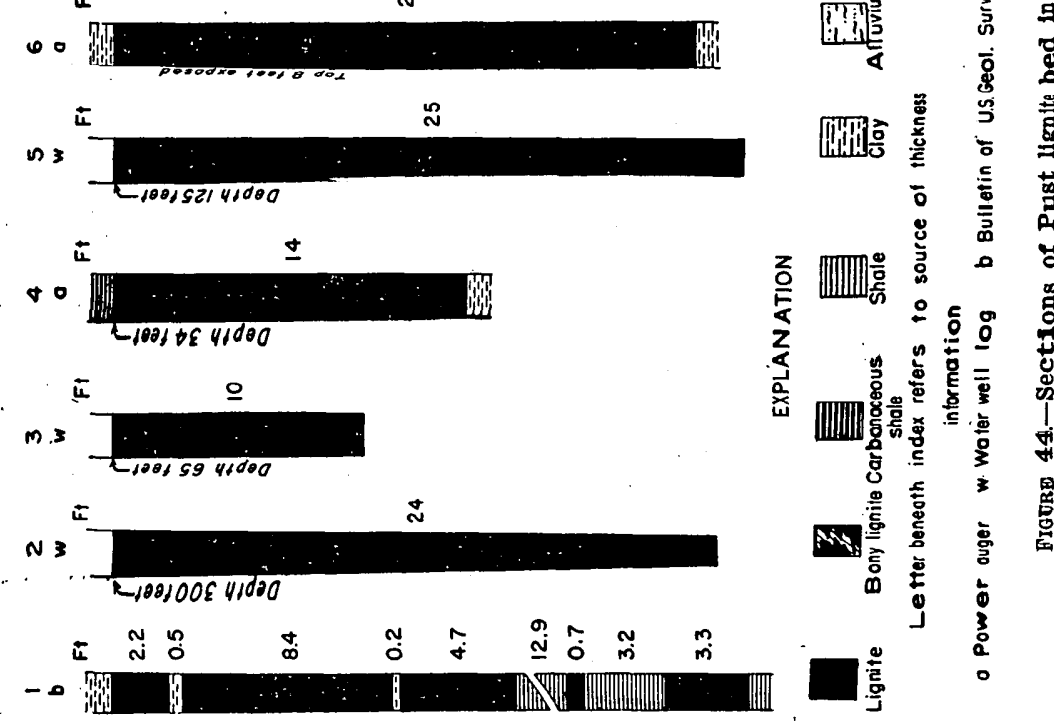


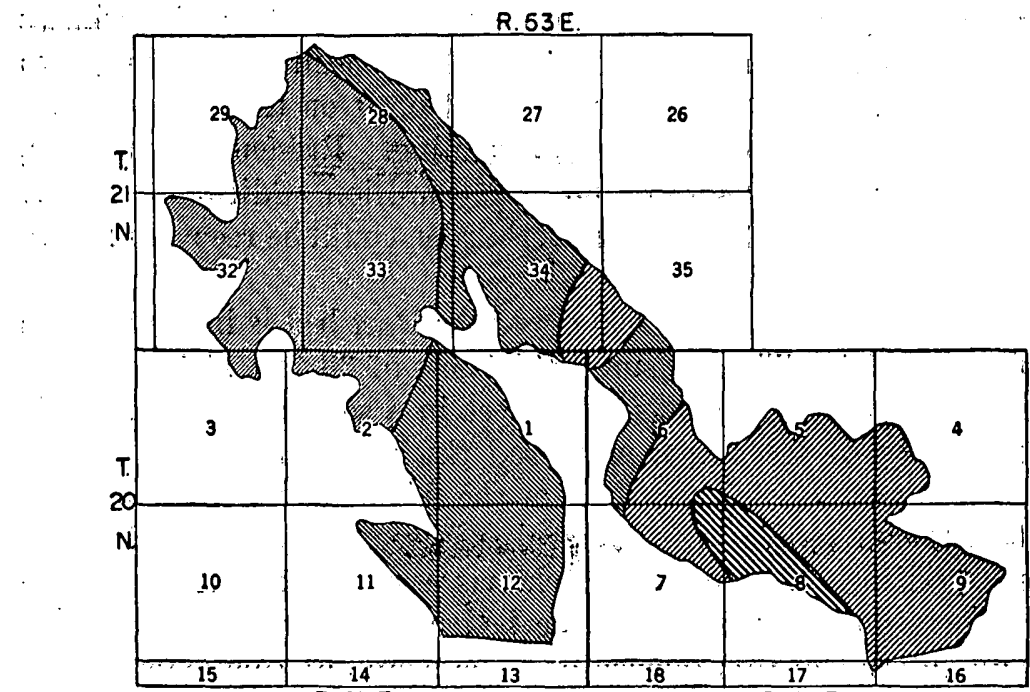

R. $53 \mathrm{E}$.

EXPLANATION

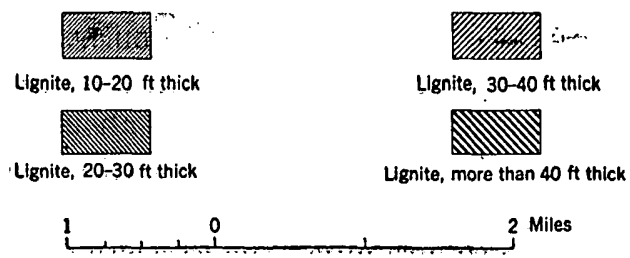

Figdrk 45.-Map showing distribution of thickness of Pust lignite bed in North Fork Thirteenmile Creek deposit.

location 11 (pl. 47), a sandy alluvium was found on top of the lignite. The floor rock is a gray clay.

Reserves and stripping ratio.-The original reserves of strippable lignite in this deposit total 225.1 million tonș under less than 120 feet of overburden. Nearly half of this amount, or 103.5 million tons, is under less than 60 feet of overburden. Because the reserves are distributed unevenly throughout the deposit, they are tabulated according to the townships in which they occur so as to give a better picture of their distribution. (See table 1.)

The average stripping ratio for this deposit, as expressed in cubic yards of overburden per ton of lignite, ranges from about 1:1 for the reservesunder less than 60 feet of overburden in:T. $20 \mathrm{~N}, \mathbf{R} \cdot \mathbf{- 5 4} \mathbf{E}$. to about 3.5: 1 for the reserves under less than 120 feet of overburden in T. 21 N., R. 53 E. The average stripping ratio for all of the reserves is about 3 cubic yards of overburden per ton of lignite.

Possible extension of the deposit.-The mapping of the North Fork Thirteenmile Creek deposit was terminated in sec. 12, T. 20 N., R. 53 E., and sec. 9, T. 20 N., R. 54 E., because the approach of winter 
prevented the gathering of sufficient data on the depth and thickness of the Pust bed to warrant extending the deposit. However, two large areas that are continuous with the deposit on the south appear. to have excellent possibilities for strip mining. Present information, though meager, indicates that 100 to 150 million additional tons of lignite under less than 120 feet of overburden could be recovered from these areas.

In T. 20 N., R. 54 E., the thickness of the Pust bed is inferred from the following data: The measured thickness of 38 feet at location 11 (pl. 47) ; a reported thickness of 40 feet in a seismograph shot hole in the vicinity of sec. 22 ; a measured thickness of 32 feet in two benches separated by 4 feet of clay at the Albrecht mine in sec. 31 ; a reported thickness of 30 feet in a mine in sec. 8, T. 19 N., R. 55 E. (Bureau of Mines, 1932, p. 87) ; thick masses of clinker along the outcrop. These data indicate that the bed may average 30 feet thick along its outcrop in this township. The shape of this extension of the strippable deposit would probably resemble a wedge with the wide end northward, for the outcrop of the Pust bed approaches the steep eastern side of the valley as it continues southward. Thus, the strip of lignite between the outcrop and the line representing 120 feet of overburden would narrow from a width of about a mile in secs. 15, 16, and 22 to a few hundred feet at the southeast corner of the township. As the area of lignite under less than 120 feet of overburden would probably be about 3 square miles, the reserves would total from 50 to 100 million tons.

In T. 20 N., R. 53 E., the only measurement of the Pust bed outside of the strippable deposit is at location 12 (pl. 47), where a well. driller reported that the bed was 29 feet thick in two benches. However, the outcrop of the bed, which curves westward from sec. 13 and passes through secs. 14,15 , and 16 , is marked almost everywhere by a large thickness of clinker. The bed thus may average 20 feet thick over a large area. The lignite under less than 120 feet of overburden probably underlies $3-4$ square miles in the wide, shallow valley in secs. $3,9,10,11,14,15$, and 16 . If this is true the strippable reserves total from 50 to 75 million tons,

BREEZY FLAT DEPOSIT

The Breezy Flat deposit is tho largest of the deposits described in this report and contains more than 200 million tons of strippable lignite.

The deposit (pl. 48 ) is in T. 20 N., R. 57 E:, Richland County, Mont., and extends a short distance into secs. 12, 24, and 25, T. 20 N., R. 56 E., Dawson County, Mont. It is 4 miles west of and 400 feet higher than 
the town of Savage, a small community on the west bank of the Yellowstone River.

State Highway 14 and a branch line of the Northern Pacific Railway pass through Savage. Breezy Flat is reached from Savage by means of a good gravel road that crosses the middle of the deposit. It also has roads or trails on nearly every section line, and consequently all parts of the deposit are readily accessible. The area is part of the Sidney lignite field (Stebinger 1912, p. 310).

Topography and land use.-Breezy Flat is a nearly isolated remnant of a high, gently sloping terrace of the Yellowstone River. Most of the surface is flat, or nearly so; but, in the western third of this area, several hills rise 40 to 100 feet above the terrace. These hills, capped by remnants of still older terrace gravel deposits, are the highest points in the mapped area and range from 140 to 200 feet above the lignite. Breezy Flat stands fairly high above the surrounding land surface, being 60 to 100 feet above the lower terrace surface to the east and as much as 200 feet above the wide stream valleys to the north, west, and south. The relatively steep slopes on the margins of this mesa-like form have, except on the west, smooth surfaces that have been cut by V-shaped valleys 10 to 90 feet deep. The western margin, however, is an abrupt escarpment that has a highly irregular surface, featuring deep gullies and canyons, long, narrow ridges, and isolated clinker-capped buttes. Because of the extremely rough terrain, that part of the Pust bed underlying the western margin is not considered economically strippable.

The deposit is drained by four intermittent tributaries of Yellowstone River: the southward-flowing North Fork of Burns Creek, the eastward-flowing Dunlap Creek, Peabody Coulee, and Garden Coulee. The average altitude of Breezy Flat is 2,400 feet above sea level, and the relief is about 100 feet.

Wheat and other small grains are raised on the central part of Breezy Flat, and cattle are pastured on the grass-covered margins.

Pust lignite bed.-The strippable lignite is in a bed that corresponds to the Pust bed of the Richey-Lambert field (Parker, 1936) and is referred to by that name in this report.

The Pust bed was measured at two surface exposures, drilled by power auger at 6 localities, and its thickness was reported from the logs of 8 water wells (fig. 46). These measurements indicate that the lignite ranges in thickness from 9 feet to at least 25 feet, and averages about 14 feet thick throughout the deposit. The Pust bed is thickest in the southern part of the deposit where it averages 18 feet thick (fig. 47). The lignite has a typical woody texture, contains small concentrations of pyrite, and, where observed, was free of partings except for a one-inch layer of clay at location 13. 

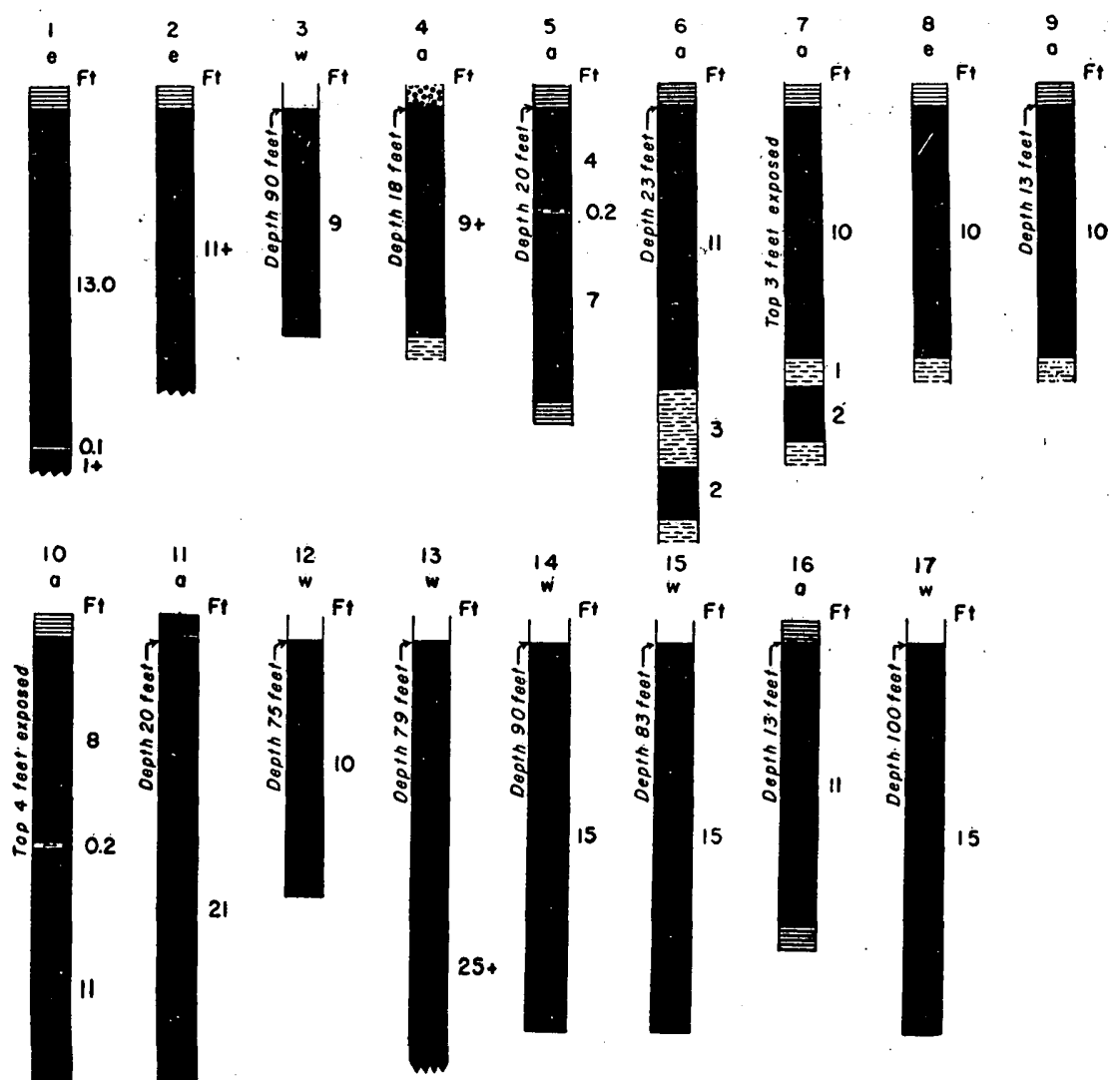

EXPLANATION

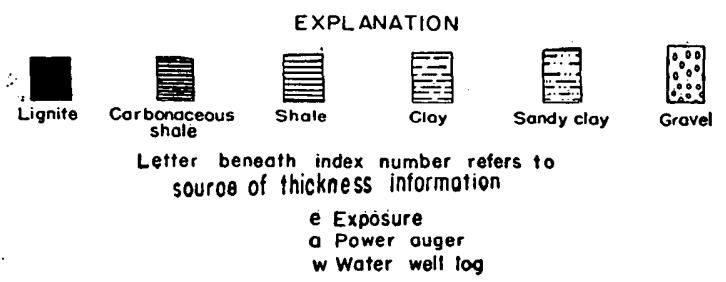

Figure 46.-Sections of the Pust liguite bed in and near the Breezy Flat strippable deposit.

The thickest measurement of the Pust bed (pl. 48, location 8) was obtained from a professional well driller, who reported that he had drilled a water well which penetrated 25 feet into the coal without reaching the base of the bed. This report was later confirmed by the owner, who had helped in drilling the well. This well, and most of the other wells in the Breezy Flat deposit, were drilled with a primitive bucket-type well borer that has been used for drilling water wells in this area since the homesteading rush of 1910-12. The borer operates in the following manner: The boring bucket, which is 30 inches in diameter, is pressed into the earth, the borer is turned by a 
horse until the bucket is full of cuttings, then the bucket is brought up and emptied. Although this procedure makes for slow well-drilling, it does give a good view of the strata penetrated, and the lignite beds can thus be measured fairly precisely.

The best place in this area to see a fresh exposure of the Pust bed is at the Chimney Rock mine, a drift mine in NW1/4 sec. 11, T. 20 N.,

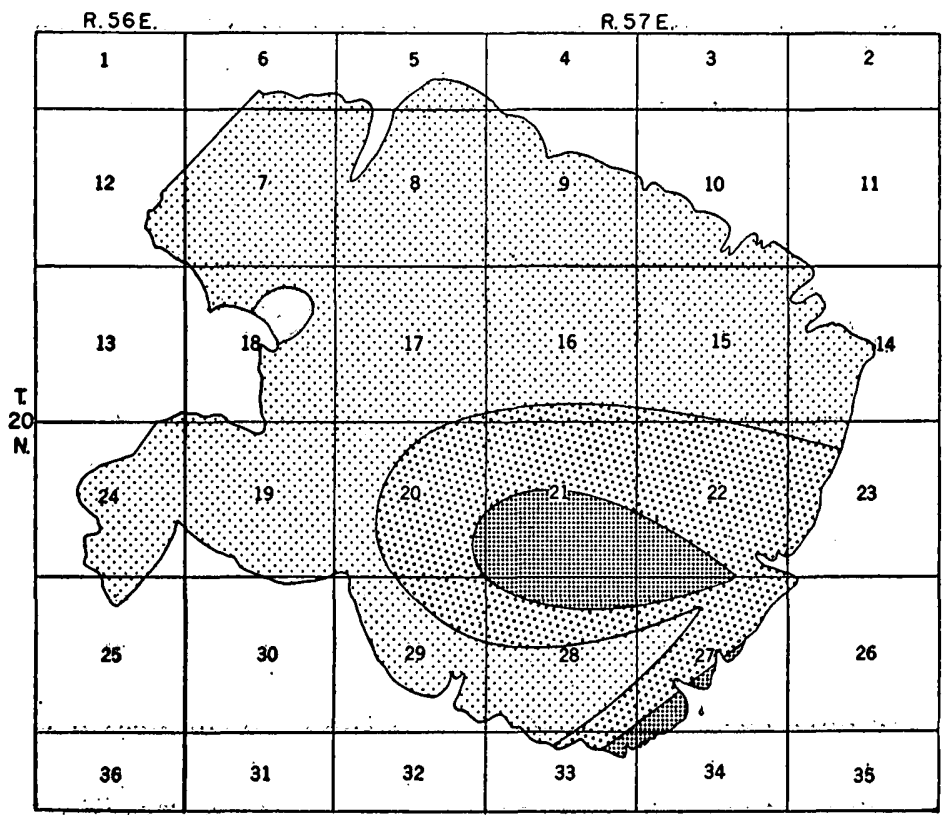

EXPLANATION
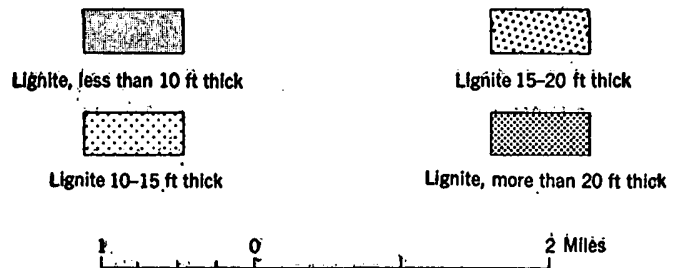

2 Milès

Froure 47.-Map showing distribution of thickness of Pust lignite bed in the Breezy ìlat strippable deposit.

R. 56 E., about 2 miless west of the deposit. (See pl. $45-\dot{B}$.) An analysis of a channel sample from this mine is presented in table 3.

The bottom few feet of the Pust bed probably contains a considerable amount of groundwater, for the local water supply is derived from wells that are drilled to the bottom of this bed. Strip pits probably could be drained easily, however, for the lignite bed is above the stream valleys that drain the area. The dip of the bed is about 15 feet per mile to the éast $=$ northéast. 
Overburden and floor rock.-The overburden on the Pust bed is composed predominantly of thick beds of poorly consolidated yellow or white sandstone interbedded with light-gray shale and a few thin beds of carbonaceous shale. In addition, a layer of well-rounded gravel underlies the entire surface of Breezy Flat, ranging in thickness from 5 to 30 feet and probably averaging about 15 feet. The fow large boulders that are found on the surface are presumably of glacial origin and thus would not be encountered beneath the surface. The floor rock beneath the lignite is a soft gray or gray-blue clay.

Reserves and stripping ratio.-The stripping of 60 feet of overburden from this deposit would uncover 70 million short tons of lignite (see table 1) in an area which, except for the valley of Peabody Coulee, consists of a narrow band around the dissected margin of the deposit. A much larger amount, 188 million short tons, would be uncovered by stripping up to 90 feet of overburden in a large compact area for which the stripping ratio would be from $4 \frac{1}{2}$ to 5 cubic yards of overburden per ton of lignite. In the southeast quarter of the deposit, where the lignite is the thickest, about 60 million tons lies under less than 90 feet of overburden and can be mined at a stripping ratio of about 3 cubic yards per ton.

The presence of a gravel deposit beneath the surface of Breezy Flat indicates that any lignite under less than about 30 feet of overburdenthe maximum observed thickness of the gravel deposit-if not eroded away may have been badly weathered at the time the gravel was deposited. Because of the compact nature of the deposit, only the lignite underlying the margins would be thus affected. The amount of reserves so affected is not known, but it is probably small; therefore, no attempt was made to correct the estimate of reserves for this factor.

A water-well driller reported that he did not encounter lignite in a well in the SE1/4 NE1/4 SE1/4 sec. 8 , T. 20 N., R. 57 E., at the depth at which the Pust bed was expected. Inasmuch as the bed is at least 10 feet thick at localities on all sides of the well, it is probable that the bed has been removed only locally, possibly by channel erosion during deposition of the terrace gravel, and that the area of missing lignite is no larger than about 100 acres, This acreage was therefore excluded from the estimate of reserves.

. Possible extensions of the deposit.-The thick clinker along the North Fork of Burns Creek in secs. 1, 2, and 12, T. 20 N., R. 56 E., and the more than 25-foot thickness of lignite at the Chimney Rock mine indicate that the Pust bed maintains an average thickness of more than 10 feet beneath the low, wide pass between Dunlap Creek and the North Fork of Burns Creek. Definite information as to the thickness and depth of this bed was: insufficient, however, to warrant extending the mapped deposit to Burns Creek, and it was terminated in secs. 6 
and 7, T. 20 N., R. 57 E. It is probable that intensive drilling would reveal an additional 15 to 25 million short tons of lignite under less than 120 feet of overburden in this pass.

\section{LITERATURE CITED}

Alden, W. C., 1932, Physiography and glacial geology of eastern Montana and adjacent areas: U. S. Geol. Survey Prof. Paper 174, 133 p.

American Society for Testing Materials, 1939, Standard specifications classification of coals by rank, (ASTM Designation: D 388-38) : Book of ASTM Standards, pt. 3, p. 1-6.

Averitt, Paul, and Berryhill, L. R., 1950, Coal resources of the United States: U. S. Geol. Survey Circ. 94, 33p.

Brown, Andrew ; Culbertson, W. C. ; Dunham, R. J.; Kepferle, R. C., and May, Paul R., 1954, Selected deposits of strippable coal in southern Custer and northern Powder River Counties, Montana: U. S. Geol. Survey Bull. 995-E.

Calvert, W. R., 1912, Geology of certain lignite fields in eastern Montana: U. S. Geol. Survey Bull. 471-D, p. 187-201.

Combo, J. X. ; Brown, D. M. ; Pulver, H. F., and Taylor, D. A., 1949, Coal resources of Montana: U. S. Geol. Survey Circ. 53, $28 \mathrm{p}$.

Combo, J. X.; Holmes, C. N., and Christner, H. R., 1950, Map showing coal resources of Montana, Scale, 1 inch to about 8 miles: Geol. Survey Coal Inv. map $\mathrm{C} 2,2$ sheets.

Corps of Engineers, 1948, Report to the U. S. Bureau of Mines on the survey of southeastern Montana for areas suitable for synthetic liquid fuel plants: Office, Chief of Engineers, Washington, D. C.

Hance, J. H., 1912, The Glendive lignite field, Dawson County, Montana : U. S. Geol. Survey Bull. 471-D, p. 271-283.

Kepferle, R. C., 1954, Selected deposits of strippable coal in central Rosebud County, Montana: U. S. Geol. Survey Bull. 995-I.

Koenig, R. P., Āpril 1950, Económics and techniques of strip coal mining: Colorado School of Mines Quart., v. 45, no. 2-B, p. 27-39.

May, P. R., 1954, Selected strippable lignite deposits in the Wibaux area, Richland, Dawson, and Wibaux Counties, Montana, and Golden Valley County, North Dakota : U. S. Geol. Survey Bull. 995-G.

Parker, F. S., 1936, The Richey-Lambert coal field, Richland and Dawson Counties, Montana: U. S. Geol. Survey Bull. 847-C, p. 121-174.

Rogers, G. S., 1917, Baked shale and slag formed by the burning of coal beds: U. S. Geol. Survey Prof. Paper 108-A, p. 1-10.

Stebinger, Eugene, 1912, The Sidney lignite field, Dawson County, Montana : U. S. Geol. Survey Bull. 471-D, p. 284-318.

U. S. Bureau of Mines, 1932, Analyses of Montana coals: Tech. Paper 529, 129 p.

U. S. Bureau of Mines, Nov. 1951, Mineral Industry Surveys, Bituminous coal and lignite in 1950 : Mineral Market Report No. 2032, 90 p.

U. S. Geol. Survey Water Supply Papers, 1935 to 1950 incl., Surface Water Supply of the United States, part 6, Missouri River Basin.

Young, W. H., June 1952, What does overburden average?: Coal Age, v. 57, no. 6, p. 104. 